Milena D. Milošević ${ }^{,}$Dunja D. Daničić ${ }^{2}$, Jovanka N.

Kovačina ${ }^{2}$, Mladen D. Bugarčić ${ }^{3}$, Jelena D. Rusmirović ${ }^{4}$, Tihomir M. Kovačević ${ }^{4}$, Aleksandar D. Marinković ${ }^{5 *}$

${ }^{1}$ University of Belgrade, Institute of Chemistry, Technology and Metallurgy, National Institute, Department of Ecology and Techoeconomic, Belgrade, Serbia, ${ }^{2}$ University of Belgrade, Institute of Chemistry, Technology and Metallurgy, National Institute, Department of Electrochemistry, Belgrade, Serbia, ${ }^{3}$ Institute for Technology of Nuclear and Other Mineral Raw Materials, Belgrade, Serbia, ${ }^{4}$ Military Technical Institute, Belgrade, Serbia

${ }^{5}$ University of Belgrade, Faculty of Technology and Metallurgy, Department of Organic Chemistry, Belgrade, Serbia

Scientific paper

ISSN 0351-9465, E-ISSN 2466-2585

UDC:620.197.60

doi:10.5937/zasmat1901081M

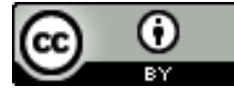

Zastita Materijala 60 (1)

$81-95$ (2019)

\title{
Modified tannins for alkyd based anticorrosive coatings
}

\begin{abstract}
The study of the synthesis of anticorrosive inhibitors, based on chemically modified tannins, and their use in alkyd based coatings to improve anticorrosive properties is presented in this work. Two methods of tannin modification were applied: direct method using ammonium hydroxide, ammonium hydroxide/ammonium chloride buffer or diethylenetriamine (DETA); and a two-step method including tannin modification with epichlorohydrin (ECH) in first step to produce epoxy modified tannin, ET, and further modification with heteroaromatic amines or linseed oil fatty acids (LFA) in second step. The obtained anticorrosive additives were characterized using ATR-FTIR, ${ }^{1} \mathrm{H}$ and ${ }^{13} \mathrm{C}$ NMR spectroscopies and elemental analysis. Epoxy, amino, hydroxyl, acid and iodine values of the synthesized inhibitors were determined according to standard methods. The prepared alkyd coating with tannin inhibitors was tested according to standard SRPS EN ISO 4628 method. Anticorrosive coating containing modified tannin based additive showed increased anticorrosive properties, good adhesion and coverage comparing to the coating with zinc phosphate additive. The alkyd coating films based on ET-LFA and ET modified with 2-amino-5mercapto-1,3,4-thiadiazole showed best anticorrosive results.
\end{abstract}

Keywords: modified tannin, anticorrosion additive, corrosion, alkyd coating.

\section{INTRODUCTION}

Development of industrial materials based on bio-renewable resources has recently drawn attention of numerous researchers, due to the reduction of fossil fuels and increasing of environment pollution caused by using of commercial non-biodegradable materials. Thus, various natural monomers, oligomers and polymers, especially resources containing polyphenolic structures (etc. flavonoids, tannins, lignin) for obtaining the high-value biopolymer materials are explored [1]. Tannin is a polyphenolic based biopolymer with numerous - $\mathrm{OH}$ groups, the most commonly obtained by extraction from plants. Tannin belongs to a group of the most abundant natural polymers after cellulose, hemicellulose and lignin [2].

\footnotetext{
*Corresponding author: Aleksandar Marinković

E-mail: marinko@tmf.bg.ac.rs

Paper received: 12. 12. 2018.

Paper accepted: 10. 01. 2019.

Paper is available on the website:

www.idk.org.rs/journal
}

The most widely studied tannins are the condensed ones based on the flavan-3-ols, (-)epicatechin and (+)-catechin by 4-8 or 4-6 linkages, respectively [3]. They were originally used in the skin tanning industry, but thanks to the reactivity of the hydroxyl group and the aromatic ring, tannins easily react with other substances, resulting in materials with improved physical and chemical properties and therefore their wide application. So, today tannins are increasingly used in medicine [4], enology [5], as raw material for the production of chemicals [6], additives [7] as well as polymeric materials for adhesives [8] and construction industry [9].

Corrosion problems have been usually solved by the selection of suitable materials that slow down the oxygen penetration to the metal surfaces. Anticorrosive protection mechanism of metal and steels is most commonly based on layering the organic coatings and paint adhesions on the substrate $[10,11]$. Many organic compounds have been investigated to explore their corrosion inhibition potential in recent years [12]. The adsorption of protective layer depends mainly on its chemical structure, such as surface functional groups, steric factors, aromaticity, electron density 
at donor atoms and the orbital character of donating electrons [13]. Usually, in protective coatings, tannin is used in combination with commercial corrosion inhibitors such as phosphate salts of zinc, iron and manganese [11,14]. Phosphate or sulphide based coatings are toxic and cause global pollution. So, tannin and its modified products are increasingly used for biorenewable additives/inhibitors in corrosion protective coatings $[6,15]$.

The aim of this study is investigation of the novel inhibitors obtained from the bio-based natural material tannin and their potential application in the industrial production of the anticorrosive protective coatings. Specific objectives of this study were focused on: (1) the introduction of amino functionalities within the tannin structure in reaction with inorganic nitrogen compounds; (2) the introduction of the epoxy groups onto tannin surface via reaction with epichlorohydrin; (3) the introduction of heterocyclic amine moieties via epoxy groups, without neat tannin structure transformation; (4) the introduction of linseed oil fatty acids via epoxy groups in order to provide higher reactivity and compatibility with alkyd resin matrix; and (5) the evaluation of anticorrosive properties of alkyd resin/modified tannin based coatings.

\section{EXPERIMENTAL}

\subsection{Materials}

In this study commercial condensed tannin as standard material and tannin extracted from oak bark were used. Commercial tannins were supplied by Sigma Aldrich. Mild steel standard plate was used in this study. All commercially available chemicals: methanol $\left(\mathrm{CH}_{3} \mathrm{OH}\right)$, potassium dihydrogen phosphate $\left(\mathrm{KH}_{2} \mathrm{PO}_{4}\right)$, potassium hydroxide $(\mathrm{KOH})$, potassium hydrogen carbonate $\left(\mathrm{KHCO}_{3}\right)$, epichlorohydrin $(\mathrm{ECH})$, sodium hydroxide $(\mathrm{NaOH})$, ethanol $\left(\mathrm{C}_{2} \mathrm{H}_{5} \mathrm{OH}\right)$, hydrochloric acid $(\mathrm{HCl})$, tetraethyl ammonium bromide (TEAB), ammonium hydroxide $\left(\mathrm{NH}_{3(\mathrm{aq})}\right)$, sodium chloride $(\mathrm{NaCl})$, 2amino-5-mercapto-1,3,4-thiadiazole, 5-aminoquinoline and 4-aminoquinoline, dimethyl sulfoxide (DMSO), diethylentriamine (DETA), pyridine, $p$ toluenesulfonyl chloride, diethyl ether, allyl chloride, diethylene glycol (DEG), pentaerythritol (PE), trimethylol propane (TMP), phthalic anhydride (PA), tetrabutyltitanate (TBT) and xylene were purchased from Sigma Aldrich. Alkyd resin driers (siccative) calcium, cobalt and zirconium octoate were kindly provided by Interhem Company Ltd. All chemicals were used without further purification. PET (polyethylene terephtalate) flakes as raw material were obtained by the grinding of colorless postconsumer bottles. The ground pieces (approximately $5 \times 5 \mathrm{~mm}$ ) were washed with acetone and dried at $110^{\circ} \mathrm{C}$ for $4 \mathrm{~h}$.

\subsection{Isolation of tannin from oak bark}

Polyphenol tannins were extracted from oak bark using methanol at room temperature. The extraction was done by mixing the $100 \mathrm{~g}$ of dried oak bark with $400 \mathrm{~mL} \mathrm{CH}_{3} \mathrm{OH}$ for $72 \mathrm{~h}$ at room temperature. The extraction mixture was filtered and filtrate was centrifuged for 20 minutes. Afterwards, filtrate was cooled down using an ice

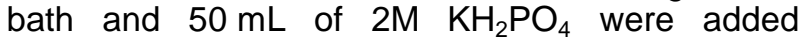
dropwise until the appearance of white fibrous precipitate. The residue was centrifuged at $1000 \mathrm{rpm}$ for ten minutes and washed with cold $\mathrm{CH}_{3} \mathrm{OH}$. Finally, the obtained product is treated with $0.5 \mathrm{M} \mathrm{HCl}$ in an ice bath with vigorous stirring for one hour. Neutralization to $\mathrm{pH} 4$ was accomplished by adding a saturated sodium carbonate solution to a tannin solution that was chilled in an ice bath. After the filtration, the tannin powder was dried and used in the further modifications.

\subsection{Epoxidation of tannin (ET)}

Modification of tannin with $\mathrm{ECH}$ was performed as follows: $10 \mathrm{~g}$ of extracted tannins were placed into a three-necked reactor equipped with a stirrer, reflux condenser and thermometer and dissolved in $100 \mathrm{~mL} 10 \mathrm{wt} \% \mathrm{NaOH}$ whereas the $\mathrm{pH}$ was adjusted to 12. Afterwards, the reaction was carried out for $1 \mathrm{~h}$ at room temperature. Further on, $43.3 \mathrm{~g}$ of $\mathrm{ECH}$ and $0.05 \mathrm{~g}$ of TEAB were added into the previously obtained mixture solution and the reaction was carried out at $80^{\circ} \mathrm{C}$, for $4 \mathrm{~h}$. After that, the reaction mixture was cooled down to room temperature and then $\mathrm{HCl}$ was added in order to adjust $\mathrm{pH}$ to 2 . The obtained product, epoxy tannin $(E T)$, was then centrifuged and dried in a vacuum oven at $40^{\circ} \mathrm{C}$.

\subsection{Isolation of unsaturated fatty acid from linseed oil}

Procedure for the isolation of fatty acids from linseed oil (LFA) has been performed analogously to the following publication [16]. In the ethanol solution of linseed oil (LO), KOH was added slowly, so that obtained molar ratio $\mathrm{KOH} / \mathrm{LO}$ was $3.5 / 1$. The reaction mixture was maintained at temperature below $10^{\circ} \mathrm{C}$ for $1 \mathrm{~h}$. Then the reaction mixture was heated up to $50^{\circ} \mathrm{C}$ for another $2 \mathrm{~h}$ whereas the $2 / 3$ of solvent were evaporated. The obtained slurry was dissolved in distilled water, purified with activated carbon, filtered and then acidified by $10 \% \mathrm{HCl}$ adjusting the $\mathrm{pH}$ to 3 . The obtained mixture was held overnight where two layers were formed, upper organic (LFA) which was decanted and the aqueous from which the LFA remains were extracted with $250 \mathrm{~mL}$ of ether and merged with LFA from the organic layer. The ether traces were evaporated after the FA solution was dried using sodium sulphate. The obtained mixture of unsaturated fatty acids weighted $180 \mathrm{~g}$. 
Obtained value for acid (AV) and iodine value (IV) of LFA corresponded to results shown in literature ( $\mathrm{AV}=200 \mathrm{mg} \mathrm{KOH} / \mathrm{g}$ and $\mathrm{IV}=150 \mathrm{~g} / 100 \mathrm{~g}$ ).

\subsection{Modification of Tannin}

2.5.1. Modification of tannin by $\mathrm{NH}_{3(\mathrm{aq})}$ : $\mathrm{AT}-1$ was obtained via tannin modification with aqueous solution of ammonia according to previously published procedure [17]. In a $25 \mathrm{~mL}$ flask $1 \mathrm{~g}$ of tannin extract was dispersed in $1 \mathrm{~mL}$ of $25 \mathrm{wt} . \%$ $\mathrm{NH}_{3(\mathrm{aq})}$. The solution was stirred for $1 \mathrm{~h}$, and left for $24 \mathrm{~h}$ in a digestor at room temperature. Further on, the resulting product AT-1 was washed with distilled water and dried at $80^{\circ} \mathrm{C}$.

2.5.2. Modification of tannin by $\mathrm{NH}_{3(\text { aq) }} / \mathrm{NH}_{4} \mathrm{Cl}$ buffer: Analogously to method presented in 2.5.1., tannin was modified with a buffer solution $\left(\mathrm{NH}_{3(\mathrm{aq})} / \mathrm{NH}_{4} \mathrm{Cl}\right)$ using a procedure described in the literature [17]. In a $25 \mathrm{~mL}$ flask, $1 \mathrm{~g}$ of tannin was dispersed in $4 \mathrm{~mL}$ of buffer solution $\mathrm{NH}_{3(\mathrm{aq})} / \mathrm{NH}_{4} \mathrm{Cl}$ and stirred for $1 \mathrm{~h}$ in order to adjust the final $\mathrm{pH}$ value to about 9 . Then, the mixture was left for $24 \mathrm{~h}$ inside the digestor for evaporation of the solvent. The solid, product AT-2, was then washed with distilled water and dried at $80^{\circ} \mathrm{C}$.

2.5.3. Modification of tannin by DETA: $1 \mathrm{~g}$ of tannin extract, $10 \mathrm{~mL}$ of DMSO and $1.5 \mathrm{~mL}$ of DETA were placed into the reactor and reaction was carried out at room temperature with vigorous stirring for $1 \mathrm{~h}$. The obtained viscous liquid was left for $24 \mathrm{~h}$ at room temperature and then $0.5 \mathrm{~mL}$ $\mathrm{C}_{2} \mathrm{H}_{5} \mathrm{OH}$ were added dropwise in order to precipitate the product. The isolated product, AT-3, was vacuum filtered and dried to constant mass.

\subsubsection{Reaction of epoxy tannin (ET) with heteroaromatic amine}

After the epoxidation, ET was subjected to amination, i.e. nucleophilic substitution reaction, using heterocyclic amines: 2-amino-5-mercapto1,3,4-thiadiazole (A1), 4-aminoquinoline (A2) or 5aminoquinoline (A3) to obtain anticorrosion additives. According to common procedure, $5 \mathrm{~g}$ of ET were dissolved in $30 \mathrm{~mL}$ of DMSO and then $9 \mathrm{~g}$ of heterocyclic amine (A1, A2 or A3) were added in the reaction mixture. The mixture was kept at room temperature for 30 minutes, afterwards the temperature was increased to $50^{\circ} \mathrm{C}$ and the reaction was carried out for $3 \mathrm{~h}$. Reaction mixture was maintained for the next $24 \mathrm{~h}$ and the obtained products (ETA-1, ETA-2 and ETA-3) were filtered, dissolved in DMSO, precipitated by addition of water, and dried to a constant mass.

\subsubsection{Reaction of epoxy tannin with fatty acids isolated from linseed oil}

In a three-necked round reactor with provided nitrogen atmosphere, condenser, thermometer and a dropping funnel, $0.5 \mathrm{~g}$ of $\mathrm{ET}$ and $100 \mathrm{~mL}$ of pyridine were charged. Then, $3.5 \mathrm{~g}$ of $p$ - toluenesulfonyl chloride and $5 \mathrm{~mL}$ of LFA mixture were added dropwise into the reactor. After stirring for $3 \mathrm{~h}$, the reaction mixture was centrifuged for 10 minutes, filtered and vigorously washed with distilled water. The obtained product ET-LFA was dried in a vacuum oven at $40{ }^{\circ} \mathrm{C}$ to a constant mass and further used in the production of anticorrosive coatings.

\subsection{Synthesis of waste PET based alkyd resin}

The glycolysis of waste PET was carried out in a $500 \mathrm{~mL}$ four-necked flask equipped with a thermometer, nitrogen inlet tube, a reflux condenser and a mechanical stirrer. DEG was used for PET recycling: $96 \mathrm{~g}$ of PET, equivalent to $0.48 \mathrm{~mol}$ of the repeating unit in the PET chain, $1.44 \mathrm{~mol}$ of DEG and $0.28 \mathrm{~mL}$ of TBT were charged to the reactor. The reaction mixture was heated at $210{ }^{\circ} \mathrm{C}$ under nitrogen atmosphere for $6 \mathrm{~h}$. At the beginning, the reaction mixture was heterogeneous (solid PET and liquid alcohol) but, after 3-4 $\mathrm{h}$ the solid phase was no longer observed and the reaction continued in one single liquid phase. After completion of the glycolysis, reaction mixture was dissolved in dichloromethane and washed two times with $150 \mathrm{~mL}$ of distilled water in order to remove excess alcohol. Afterwards, the mixture was filtered with a sintered glass filter (Borosil Glass Works Ltd, porosity grade 3) and dried at $80{ }^{\circ} \mathrm{C}$ for $12 \mathrm{~h}$. Then, the formed viscous solution was poured into distilled water, whereas the temperature was maintained at $50^{\circ} \mathrm{C}$. The efficient mixing of the obtained emulsion was necessary (using a mechanical stirrer), over the whole period of addition and thereafter during slow temperature decrease (without external cooling). Approaching the room temperature, the rate of stirring was proportionally decreased, providing separation of the upper aqueous phase. The hydroxyl number $(\mathrm{HV})$ of the glycolyzed product was found to be $317 \mathrm{mg} \mathrm{KOH} / \mathrm{g}$.

Alkyd resin, having oil contents of $\sim 48 \%$, based on glycolysis product was synthesized in the next step. The amounts of reactants were calculated using a method based on the alkyd constant value [18]. Synthesis was performed according to the procedure presented in the literature [19]. A fournecked reactor equipped with a stirrer, thermometer, nitrogen inlet tube and Dean-Stark separator for water separation with xylene as azeotropic solvent were used. In a $500 \mathrm{~mL}$ glass reactor $80.8 \mathrm{~g}$ of glycolysis product, $172 \mathrm{~g}$ of LFA, $88.8 \mathrm{~g}$ of PA, $28.4 \mathrm{~g}$ of PE and TMP were added in the reactor, and the reaction mixture was heated to $220^{\circ} \mathrm{C}$ with continual azeotropic water removal. The time-dependent change of acid value (AV) was followed according to a standard method [20], and the reaction product was diluted to $60 \%$ of the solid content with xylene when the AV was $<15 \mathrm{mg}$ $\mathrm{KOH} / \mathrm{g}$. 


\subsection{Preparation of alkyd based anticorrosive coatings}

Alkyd resin based anticorrosive coatings were prepared via blending method by mixing of the determined amount of alkyd resin, additives and anticorrosive agent according to composition given in Table 1 (in wt.\%).

Table 1. Composition of the anticorrosive alkyd based coatings with commercial and synthesized anticorrosive agents

Tabela 1. Sastav antikorozionih premaza sa komercijalnim i sintetisanim antikorozionim agensima

\begin{tabular}{|c|c|c|c|c|c|c|c|c|}
\hline \multirow{2}{*}{ Component, g } & \multicolumn{8}{|c|}{ Composition } \\
\hline & 0 & 1 & 2 & 3 & 4 & 5 & 6 & 7 \\
\hline Alkyd resin (long oil) & 30.0 & 30.0 & 30.0 & 30.0 & 30.0 & 30.0 & 30.0 & 30.0 \\
\hline Xylene & 1.0 & 1.0 & 1.0 & 1.0 & 1.0 & 1.0 & 1.0 & 1.0 \\
\hline Toluene & 9.0 & 9.0 & 9.0 & 9.0 & 9.0 & 9.0 & 9.0 & 9.0 \\
\hline *Bentone & 3.5 & 3.5 & 3.5 & 3.5 & 3.5 & 3.5 & 3.5 & 3.5 \\
\hline Dispersant & 0.3 & 0.3 & 0.3 & 0.3 & 0.3 & 0.3 & 0.3 & 0.3 \\
\hline Talc & 5.0 & 5.0 & 5.0 & 5.0 & 5.0 & 5.0 & 5.0 & 5.0 \\
\hline${ }^{* *}$ Anticorrosive additive & 0.0 & 2.5 & 2.5 & 2.5 & 2.5 & 2.5 & 2.5 & 2.5 \\
\hline Zinc Phosphate & 6.0 & 0.0 & 0.0 & 0.0 & 0.0 & 0.0 & 0.0 & 0.0 \\
\hline ***Pigment & 6.5 & 6.5 & 6.5 & 6.5 & 6.5 & 6.5 & 6.5 & 6.5 \\
\hline $\mathrm{Ca}(5 \%)$ & 1.0 & 1.0 & 1.0 & 1.0 & 1.0 & 1.0 & 1.0 & 1.0 \\
\hline $\mathrm{Zr}(12 \%)$ & 0.8 & 0.8 & 0.8 & 0.8 & 0.8 & 0.8 & 0.8 & 0.8 \\
\hline Co $(6 \%)$ & 0.2 & 0.2 & 0.2 & 0.2 & 0.2 & 0.2 & 0.2 & 0.2 \\
\hline $\mathrm{CaCO}_{3}(20 \mu \mathrm{m})$ & 36.0 & 39.5 & 39.5 & 39.5 & 39.5 & 39.5 & 39.5 & 39.5 \\
\hline Anti-skinning agent & 0.7 & 0.7 & 0.7 & 0.7 & 0.7 & 0.7 & 0.7 & 0.7 \\
\hline
\end{tabular}

${ }^{*} 10 \%$ Bentone in toluene with $10 \%$ ethanol; **anticorrosive additive: coating with AT-1 inhibitor was named Co-AT1, AT-2 (Co-AT2), AT-3 (Co-AT3), ETA-1 (Co-ETA1), ETA-2 (Co-ETA2), ETA-3 (Co-ETA3), and ET-LFA (Co-ETLFA) (coating system); Composition 0 is denoted as Co-1 and represent a comparative sample with addition of Zinc Phosphate; ${ }^{* * *}$ Iron oxide was used as pigment

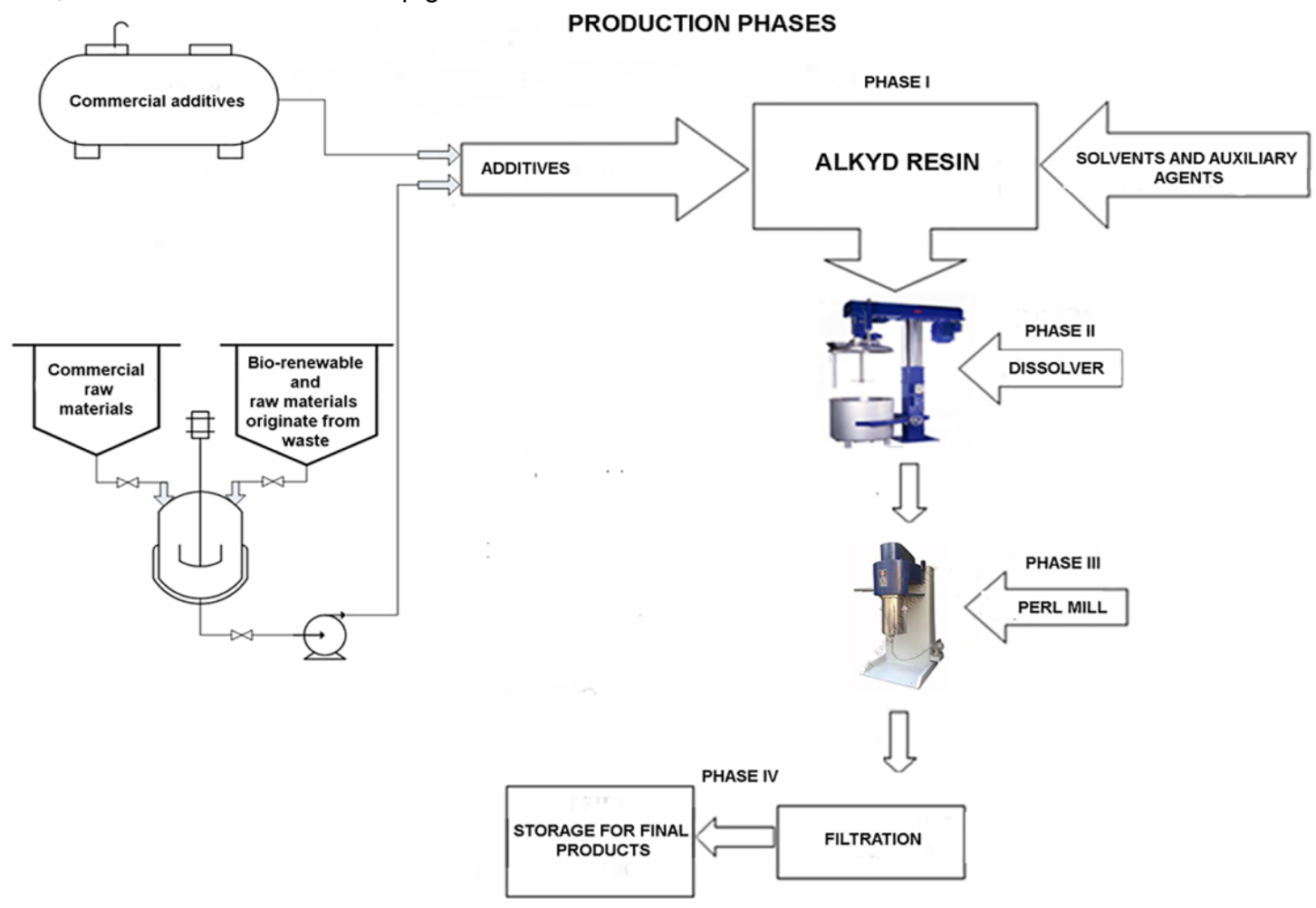

Figure 1. Schematic presentation of production of the alkyd based anticorrosive coatings at industrial level Slika 1. Šematski prikaz proizvodnje alkidnih antikorozionih premaza na industrijskom nivou 
Schematic overview of alkyd based anticorrosive coating production at industrial level $(50 \mathrm{~kg}$ ) is shown in Figure 1 (batch of $30 \mathrm{~kg}$; Interhem Company, Belgrade). Analogous technology was applied at laboratory level $(0.3 \mathrm{~kg})$. In the first step of anticorrosive coating production, alkyd resins were mixed with components (at amount given in Table 1) in the high speed dissolver, $1300 \mathrm{rpm}$ for 40 minutes, and after addition of alkyd resin, driers and anti-skinning agents mixing was continued for additional $10 \mathrm{~min}$. Afterwards, in the second step fine dispersion of anticorrosive coating was obtained using a pearlmill by treating of dispersion for 30 minutes at $1840 \mathrm{rpm}$. The degree of grinding of alkyd coatings was checked using grindometer, and process was adjusted to obtain standard quality of product, while the viscosity was adjusted by addition of xylene. Filtration with polypropylene membrane filter $(15 \mu \mathrm{m})$ was performed to remove any agglomerates which could create a defect in the anticorrosive coating after application on mild steel base. Production of anticorrosive coatings at industrial level is presented on Figure 1.

\subsection{Characterization methods}

The chemical structure of extracted and modified tannin was proved by ATR-FTIR method. The ATR-FTIR spectra were recorded in the range $4000-500 \mathrm{~cm}^{-1}$ with a resolution of $4 \mathrm{~cm}^{-1}$ at room temperature using Nicolet iS10 (Thermo Scientific) spectrometer. ${ }^{1} \mathrm{H}$ and ${ }^{13} \mathrm{C}$ NMR spectra were recorded at room temperature in DMSO- $d_{6}$ using Varian Gemini 2000 spectrometer at $200 \mathrm{MHz}$ for ${ }^{1} \mathrm{H}$ NMR and $50 \mathrm{MHz}$ for ${ }^{13} \mathrm{C}$ NMR. The chemical shifts were expressed in ppm value referenced to trimethylsilane (TMS). Elemental analyses were performed using a Vario EL III Elemental analyzer.

Epoxy number was determined using $0.4 \mathrm{M}$ $\mathrm{HCl}$ in dioxane and titration with solution of silver nitrate in presence of the ammonium thiocyanate as indicator according to the standard method [21]. The epoxy index (El) was then calculated as follows:

$$
\text { epoxy } \%=\frac{(\mathrm{B} \times \mathrm{N}-\mathrm{b} \times \mathrm{n})-(\mathrm{S} \times \mathrm{N}-\mathrm{s} \times \mathrm{n})}{10 \times \mathrm{W}}+\mathrm{A}
$$

where: $B$ and $S$ are volumes of silver-nitrate solution labeled in $\mathrm{mL}$ for blank and sample respectively; $\mathrm{N}$ is the normality of silver nitrate for blank; $b$ and $s$ are the volumes of ammoniumthiocyanate labeled in $\mathrm{mL}$ for blank and sample respectively; $n$ normality of ammonium thiocyanate; $\mathrm{W}$ is the sample weight labeled in $\mathrm{g}$ and $\mathrm{A}$ free halide in sample.

Amino value $(\mathrm{AmV})$ was determined by the standard method ASTM D2074-92 [22].
The hydroxyl value (HV) of tannin was determined by the standard method ASTM E1899 [23]. The acid value (AV) was determined by standard method ASTM D3644 [20], and modified method using potassium hydrogen carbonate. The iodine value was determined by the Wijs method.

Coating film applicator was used to obtain consistent dry film thickness. Evaluation of corrosive properties of selected samples was determined according to the standard method in the salt chamber for 48 and $120 \mathrm{~h}$ [24]. The plates were covered with one or two 120-240 $\mu$ m thick layers, of an alkyd based coating. The viscosity measurement was performed using Ford viscosity cup 4 [25]. Hardness was measured by a pendulum hardness tester (Byk PH-5858, BYKGardner $\mathrm{GmbH}$, Geretsried, Germany) using a König pendulum according to the standard method [26]. Thickness of the dry film was measured according to ISO 2360 [27]. Blistering, rusting, cracking and delamination were determined according to SRPS EN ISO 4628 [24]. The adhesion of the films was determined according to SRPS EN ISO 2409 [28]. The abrasion was performed according to ASTM D 4060-10 [29]. Volatile organic compound (VOC) were determined using the standard method SRPS EN ISO 11890-1 [30]. Shine was determined using the standard method ASTM D523 - 08 [31]. Impact resistance was determined using the standard method ASTM D2794 - 93 (Re-approved 2010) [32].

The assessment of the blistering grade is made according to the density of the blisters and their size (SRPS EN ISO 4628-2) - Table 2.

Table 2. Blistering assessment according to density and size of blisters

Tabela 2. Bubrenje određeno prema gustini $i$ veličini mehura

\begin{tabular}{|c|c|c|}
\hline \multicolumn{2}{|c|}{ Density } & Size \\
\cline { 1 - 2 } ISO & AST & ISO \\
\hline 0 & None & \multirow{2}{*}{ 1 10 magnification } \\
\hline 1 & Scarce & visible \\
\hline 2 & Few & up to $0.5 \mathrm{~mm} \mathrm{0.5-5} \mathrm{mm}$ \\
\hline 3 & Medium & $>5 \mathrm{~mm}$ \\
\hline 4 & Medium-High & \\
\hline 5 & High & \\
\hline
\end{tabular}

In order to determine the degree of rusting/corrosion, a series of pictorial standards (Figure 2) must be compared with the painted surfaces. There are also tables showing the percentage area of visible rusting of the surfaces. Corrosion grades are designated by "Ri". In the table below the areas for each grade of corrosion are shown in Table 3. 


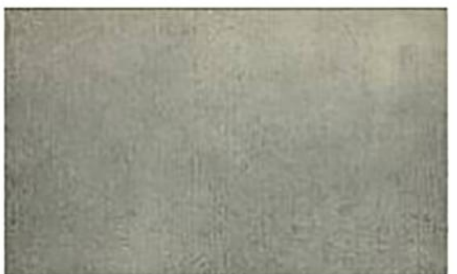

Rio

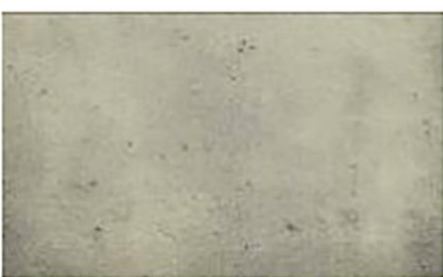

Ri1

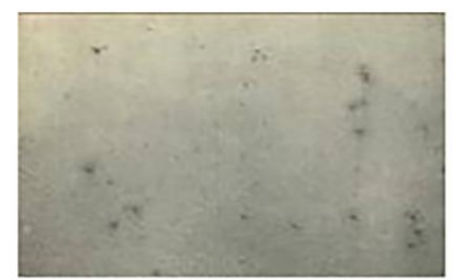

Ri2

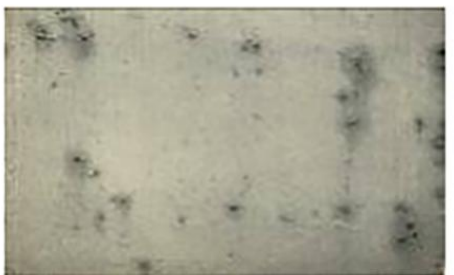

Ri3

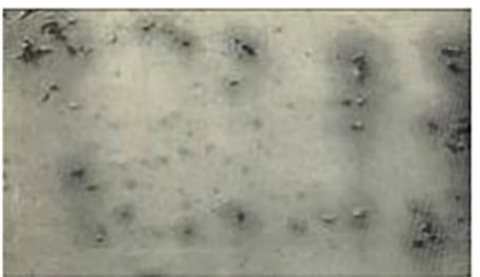

Ri4

Figure 2. Photographic examples corresponding to ISO 4628-3, to assess the degree of rusting of a painted surface

Slika 2. Antikorozioni premazi različitog stepena korozije u skladu sa ISO 4628-3 standardom

Table 3. Rusting/corrosion assessment

Tabela 3. Određivanje stepena rđe/korozije

\begin{tabular}{|c|c|c|c|}
\hline ISO & European scale & ASTM & $\%$ rusted area \\
\hline Ri0 & Re0 & 10 & 0 \\
\hline Ri1 & Re1 & 9 & 0.05 \\
\hline Ri2 & Re2 & 7 & 0.5 \\
\hline Ri3 & Re3 & 6 & 1 \\
\hline Ri4 & Re4 & 4 & 8 \\
\hline Ri5 & Re5 & $1 \mathrm{a} 2$ & $40 / 50$ \\
\hline
\end{tabular}

The assessment of the cracking grade is made according to the density of the cracks and their size (SRPS EN ISO 4628-4), Table 4.

Table 4. Cracking assessment according to density and size of cracks

Tabela 4. Određivanje pukotina prema gustini i veličini

\begin{tabular}{|c|c|l|}
\hline \multicolumn{2}{l}{ pukotine } \\
\hline 0 & None & $\begin{array}{l}\text { Not visible under x10 } \\
\text { magnification }\end{array}$ \\
\hline 1 & Very few & $\begin{array}{l}\text { Only visible under } \\
\text { magnification up to x10 }\end{array}$ \\
\hline 2 & Few & $\begin{array}{l}\text { Just visible with normal } \\
\text { corrected vision (up to } \\
0.2 \text { mm) }\end{array}$ \\
\hline 3 & $\begin{array}{c}\text { Moderate } \\
\text { number of } \\
\text { cracks }\end{array}$ & $\begin{array}{l}\text { Clearly visible with normal } \\
\text { corrected vision (larger } \\
\text { than 0.2 mm up to 0.5 mm) }\end{array}$ \\
\hline 4 & $\begin{array}{c}\text { Considerable } \\
\text { number of } \\
\text { cracks }\end{array}$ & $\begin{array}{l}\text { Large cracks (larger than } \\
\text { 0.5 mm up to 1 mm) }\end{array}$ \\
\hline 5 & $\begin{array}{c}\text { Dense pattern } \\
\text { of cracks }\end{array}$ & $\begin{array}{l}\text { Very large cracks } \\
\text { (generally more than 1 mm } \\
\text { wide) }\end{array}$ \\
\hline
\end{tabular}

\section{RESULTS AND DISCUSSION}

The overall reaction of one-step tannin modification with $\mathrm{NH}_{3(\mathrm{aq})}, \mathrm{NH}_{3(\mathrm{aq})} / \mathrm{NH}_{4} \mathrm{Cl}$ and DETA, and two-step modification via $\mathrm{ECH}$ followed by heterocyclic amines (A1, A2 and A3) are shown in Figures 3 and 4 , respectively.

The amination reaction takes place in a onestep procedure (Figure 3). The previous studies show that this reaction under mild conditions and without a catalyst is a regio-selective reaction [33, 34]. The aminated hydroxyl groups lead to oligomerization and cross-linking via connections between $\mathrm{N}$ and $\mathrm{OH}$ within the tannin molecules. Depending on which hydroxyl group of the rings $A$ or $C$ reacts and also due to the formation of imine bonds, several different structures can potentially be formed. Among many possible structures, I and III (Figure 3) are of highest probability to be established $[17,33]$. The epoxidation and amination of tannins improve the ability of tannins to form complexes which is reflected in better dispersion in various solvents making the obtained corrosion inhibitors suitable for application in metal protective coating compositions. Furthermore, due to the applied modification procedures modified tannin contributes to improved compatibility, adhesion to metal substrate, resistance to abrasion and anticorrosive properties of alkyd based coatings. Presence of nitrogen and oxygen atoms as well as $\pi$-electrons in aromatic structure of tannin enable the interaction with polymer matrix and thus better bonding between coating and the metal surface. 
<smiles>C[C@@H]1c2cc(O)cc([As])c2O[C](c2cc(O)c(O)c(O)c2)[C@H]1O</smiles>

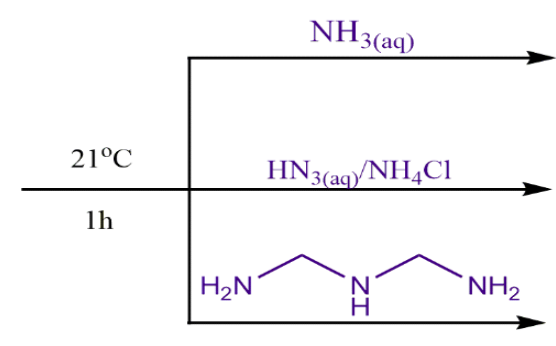<smiles>[R]Nc1ccc(C2OC3=C/C(=N/C)CC(=NC)C3CC2O)cc1O</smiles><smiles>CN=C(c1ccc(O)c(O)c1)C(O)Cc1c(O)cc(O)cc1O</smiles>

II<smiles>[R]Nc1cc(CC(O)CC2C(O)=CC(=Nc3cc(O)c(CC(O)Cc4ccc(O)c(O)c4)c(O)c3)C=C2O)ccc1O</smiles><smiles>[R]Nc1cc(O)cc(O)c1CC(O)/C(=N/c1cc(O)c(CC(O)/C(=N/C)c2ccc(O)c(O)c2)c(O)c1)c1ccc(O)c(O)c1</smiles>

R: $\mathrm{H}$ or $\mathrm{CH}_{2} \mathrm{CH}_{2} \mathrm{NHCH}_{2} \mathrm{CH}_{2} \mathrm{NH}_{2}$

IV

Figure 3. Chemical modifications of tannin with $\mathrm{NH}_{3(a q)}(A T-1), \mathrm{NH}_{3(a q)} / \mathrm{NH}_{4} \mathrm{Cl}(\mathrm{AT}-2)$ and DETA (AT-3)

Slika 3. Hemijska modifikacija tanina sa $\mathrm{NH}_{3}(\mathrm{aq})(\mathrm{AT}-1), \mathrm{NH}_{3}(\mathrm{aq}) / \mathrm{NH}_{4} \mathrm{Cl}(\mathrm{AT}-2)$ i DETA (AT-3)

Modification procedure presented in Figure 4 includes a two-step process: the first one represents tannin etherification with $\mathrm{ECH}$ to form $\mathrm{ET}$, and the second one the reaction between ET and either heterocyclic amine or LFA to form the end-product, i.e. anticorrosive inhibitors used for alkyd based coatings production. The epoxidation belongs to $S_{N} 2$ substitution reactions where epoxy groups from $\mathrm{ECH}$ are linked to hydroxyl groups (phenolic) from tannin A or B aromatic ring. In fact, reaction mechanism consists of mixed contribution of $S_{N} 2$ and epoxide ring opening reactions. Higher reactivity of the ring designated as $B$, with respect to A ring (Figure 4), is a consequence of the position of $\mathrm{OH}$ group and resonance structure [2, 33]. In general, alkaline medium, elevated temperatures and alkyl halides as catalysts favor the epoxidation reaction to produce epoxy tannin at satisfactory yield. Alkyl bromides give greater yields as they are more reactive than alkyl chlorides and less susceptible to dehydrohalogenation than alkyl iodides [2]. In any case, epoxidation is useful due to versatility/reactivity of epoxy ring, and highly desirable even at expected lower reaction yield. 


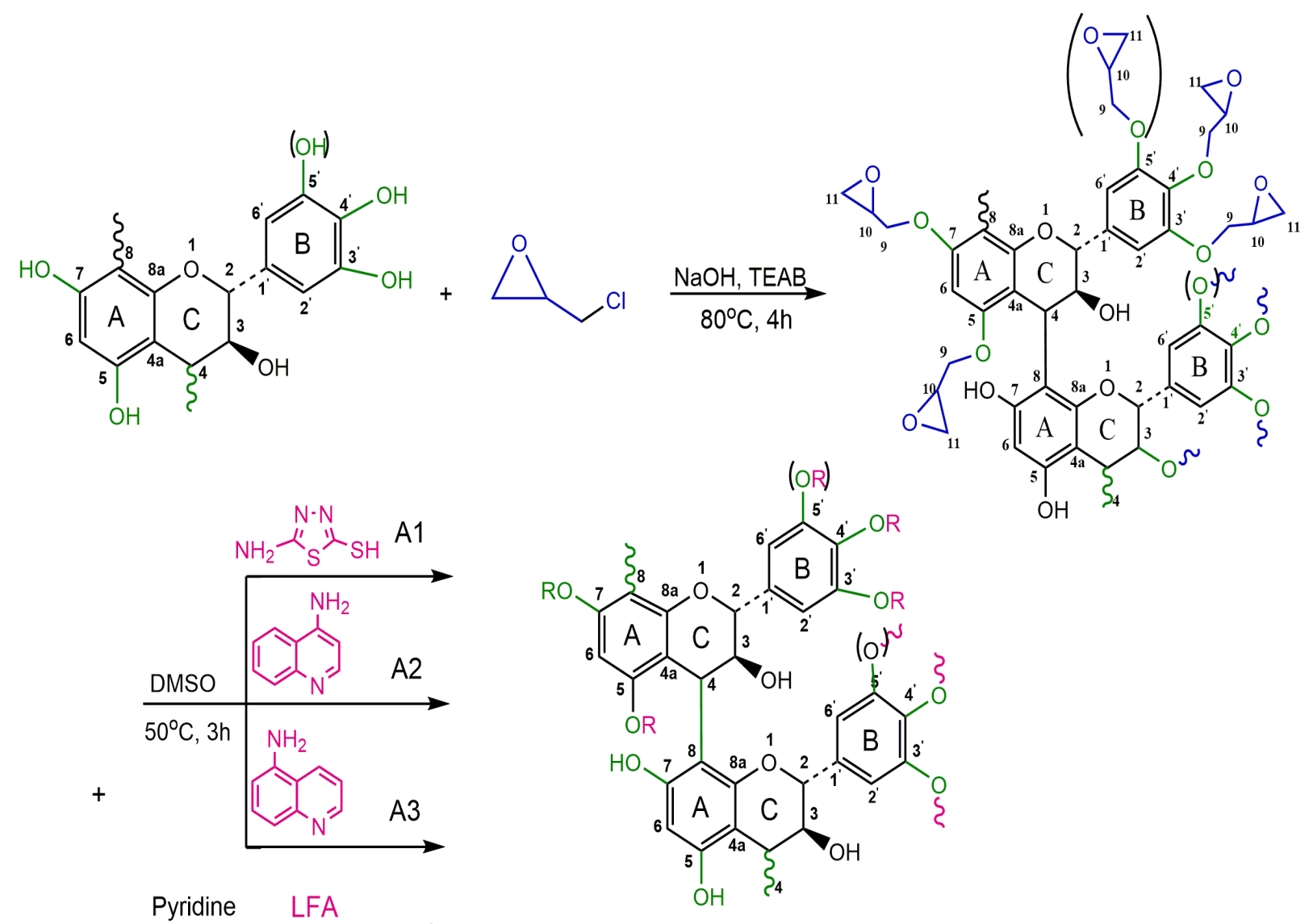<smiles>[R]OC(CC)C(=C)Nc1nnc(S)s1</smiles>

ETA-1

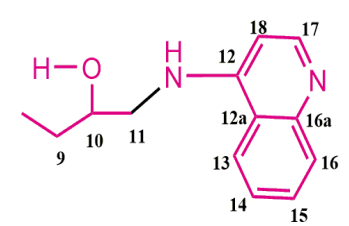

ETA-2<smiles>CCC(O)C=CNc1cccc2ncccc12</smiles>

ETA-3

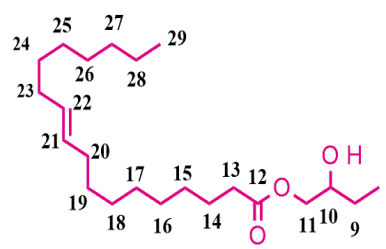

ET-LFA

Figure 4. Two-step chemical modifications of tannin with ECH (first step), and heteroaromatic amine (A1-A3) and LFA in second step

Slika 4. Dvostepena hemijska modifikacija tanina sa ECH (prvi korak), i heteroaromatičnim aminima (A1-A3) i LFA u drugom koraku

The usage of epoxy tannins as inhibitors in coatings is limited and requires additional modification via introduction of heterocyclic amines which possess inherent anticorrosive capability. The presence of amino groups leads to opening of the epoxy ring by formation of covalent linkage introducing synergetic effects of both, tannin and heteroaromatic moieties. Also, higher stability of resulting anticorrosive agent and higher compatibility with alkyd polymer matrix help in enhancement of final properties of coatings during application. The viscosity of formulated products with respect to the comparative sample (Co-1; Table 1) is similar (change within $\pm 5 \%$ ).

The HV, AV and amine value (AmV) and the data from elemental analysis of the synthesized inhibitors are presented in Table 5. 
Table 5. Results of HV, modified AV, AmV and elemental analysis of the synthesized anticorrosive inhibitors

Tabela 5. Rezultati HV, modifikovanog AV, AmV i elementalne analize sintetizovanih antikorozionih inhibitora

\begin{tabular}{|c|c|c|c|c|c|c|c|c|}
\hline Inhibitor & $\begin{array}{c}\mathrm{HV}^{*} \\
\mathrm{mg} \mathrm{KOH} / \mathrm{g}\end{array}$ & $\begin{array}{c}\mathrm{AV}^{*} \\
\mathrm{mg} \mathrm{KOH} / \mathrm{g}\end{array}$ & $\begin{array}{c}\mathrm{AmV} \\
\mathrm{mg} \mathrm{KOH} / \mathrm{g}\end{array}$ & & $\% \mathrm{C}$ & $\% \mathrm{H}$ & $\% \mathrm{O}^{\star}$ & N\% \\
\hline \multirow{2}{*}{ AT-1 } & \multirow{2}{*}{186} & \multirow{2}{*}{$<3$} & \multirow{2}{*}{110} & Calc. & 61.62 & 6.39 & 19.31 & 12.68 \\
\hline & & & & Exp. & 61.58 & 6.23 & 19.62 & 12.57 \\
\hline \multirow{2}{*}{ AT-2 } & \multirow{2}{*}{177} & \multirow{2}{*}{$<3$} & \multirow{2}{*}{140} & Calc. & 63.82 & 5.71 & 25.50 & 4.97 \\
\hline & & & & Exp. & 63.51 & 5.74 & 25.37 & 4.99 \\
\hline \multirow{2}{*}{ AT-3 } & \multirow{2}{*}{168} & \multirow{2}{*}{$<3$} & \multirow{2}{*}{160} & Calc. & 62.78 & 6.49 & 22.13 & 8.60 \\
\hline & & & & Exp. & 62.76 & 6.51 & 22.15 & 8.58 \\
\hline \multirow{2}{*}{ ET } & \multirow{2}{*}{280} & \multirow{2}{*}{$<3$} & \multirow{2}{*}{$<10$} & Calc. & 62.83 & 6.00 & 31.17 & - \\
\hline & & & & Exp. & 63.11 & 6.03 & 30.86 & - \\
\hline \multirow{2}{*}{ ETA-1 } & \multirow{2}{*}{256} & \multirow{2}{*}{$<3$} & \multirow{2}{*}{246} & Calc. & 56.33 & 5.23 & 19.16 & 14.28 \\
\hline & & & & Exp. & 56.05 & 5.20 & 19.06 & 14.21 \\
\hline \multirow{2}{*}{ ETA-2 } & \multirow{2}{*}{236} & \multirow{2}{*}{$<3$} & \multirow{2}{*}{216} & Calc. & 69.56 & 7.10 & 14.99 & 8.35 \\
\hline & & & & Exp. & 69.91 & 7.06 & 14.92 & 8.39 \\
\hline \multirow{2}{*}{ ETA-3 } & \multirow{2}{*}{248} & \multirow{2}{*}{$<3$} & \multirow{2}{*}{230} & Calc. & 68.70 & 6.16 & 17.21 & 7.93 \\
\hline & & & & Exp. & 69.04 & 6.19 & 17.29 & 7.89 \\
\hline \multirow{2}{*}{ ET-LFA } & \multirow{2}{*}{268} & \multirow{2}{*}{$<3$} & \multirow{2}{*}{$<10$} & Calc. & 71.30 & 9.65 & 19.05 & - \\
\hline & & & & Exp. & 71.45 & 9.71 & 18.81 & - \\
\hline
\end{tabular}

${ }^{*} \mathrm{HV}$ and $\mathrm{AV}$ values were evaluated for synthesis purpose (AV was determined according to modified method using $\mathrm{KHCO}_{3}$ - in case of using $\mathrm{KOH}$ AV > 150); The oxygen percent was calculated as the difference to $100 \%$; lodine value of 126 was obtained for ET-LFA sample.

The values indicate that the number of hydroxyl groups does not change significantly by performing the two-step modification procedure, while low decrease of HV after one-step modification indicates appropriate rearrangement of initial tannin structure. The experimental data of elemental analysis confirm the successfulness of applied transformation. The higher amine content was found in aminated products obtained by one-step procedure which indicates higher extent of

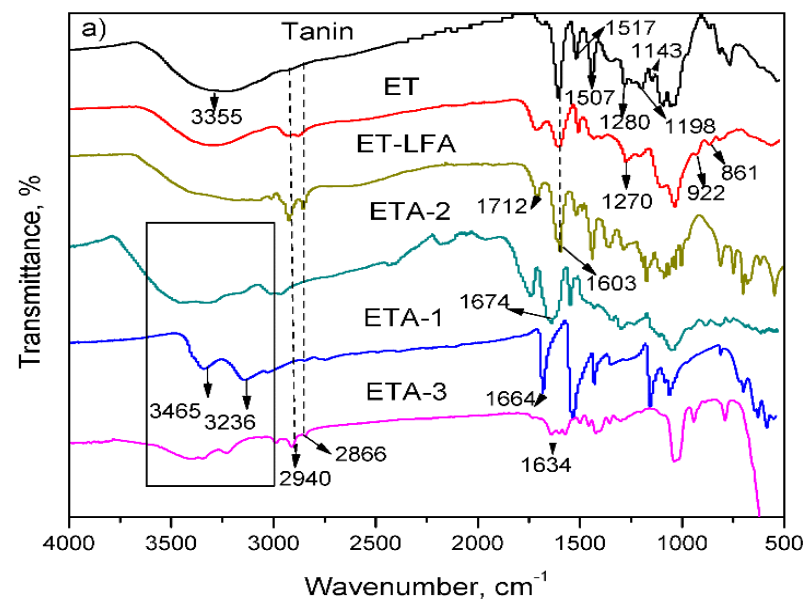

modification and basicity of ammonia reacting species.

\subsection{Results of the characterization of modified tannins using ATR-FTIR and NMR spectroscopy}

In order to confirm the structure of extracted/modified tannins, the FT-IR analysis and NMR spectroscopy were performed. The ATRFTIR spectra of pristine and modified tannins are presented in Figure 5.

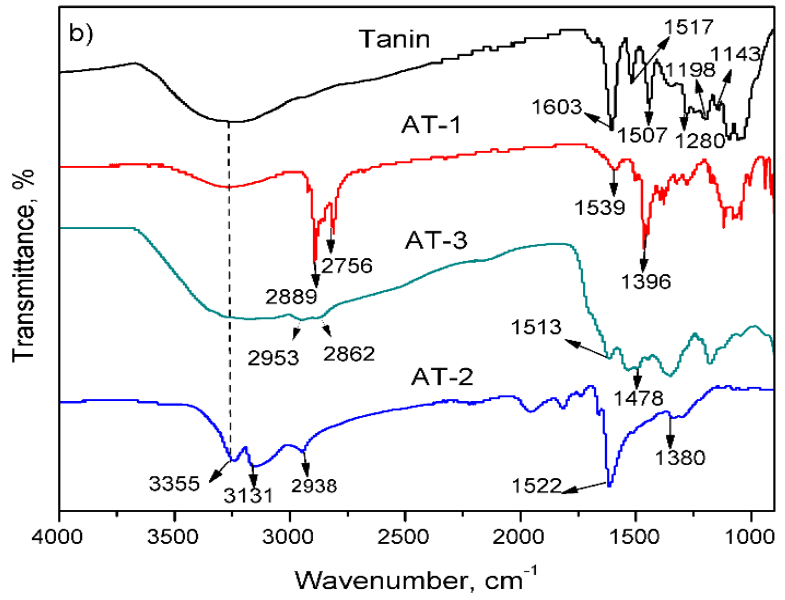

Figure 5. FT-IR spectra of modified tannins inhibitors a) ETA-(1-3) and ET-LFA, and b) AT-(1-3)

Slika 5. FT-IR spektri inhibitora na bazi modifikovanih tanina a) ETA-(1-3) i ET-LFA, i b) AT-(1-3) 
The band at $3355-3131 \mathrm{~cm}^{-1}$ is related to the presence of $\mathrm{O}-\mathrm{H}$ and $\mathrm{N}-\mathrm{H}$ stretching vibrations characteristic for polyphenol extracts and primary and secondary amines obtained by modification with amines (Figure 5a) and aqueous solution of ammonium hydroxide, ammonium buffer $\mathrm{NH}_{3(\mathrm{aq})} / \mathrm{NH}_{4} \mathrm{Cl}$ and DETA (Figure 5b). Strong signals at 1603,1517 and $1507 \mathrm{~cm}^{-1}$ are assigned for $\mathrm{C}=\mathrm{C}-\mathrm{C}$ vibrations in aromatic $\mathrm{A}$ and $\mathrm{B}$ rings of tannin. The appearance of the band at $1280 \mathrm{~cm}$ ${ }^{1}$ can be attributed to $\mathrm{C}-\mathrm{O}$ vibrations in catechol $\mathrm{C}$ ring. The peak for $\mathrm{C}-\mathrm{O}$ vibrations which originates from aromatic A ring, is found at 1198 and $1143 \mathrm{~cm}^{-1}$ [35]. After modification with $\mathrm{ECH}$, three new bands, observed at 1270, 922 and $861 \mathrm{~cm}^{-1}$, represent stretching, anti-symmetric and deformation originated from $\mathrm{C}-\mathrm{O}$ vibration in epoxy ring. The obtained data indicate that epoxy group is successfully attached onto tannin surface.

The two small broad peaks presented at 2940 and $2866 \mathrm{~cm}^{-1}$ are assigned to $\mathrm{C}-\mathrm{H}$ symmetric and asymmetric stretching vibrations of $\mathrm{CH}_{3}$ and $\mathrm{CH}_{2}$ groups. The cluster of peaks observed at 1664, 1634 and $1674 \mathrm{~cm}^{-1}$ represents the characteristic bands of $\mathrm{N}-\mathrm{H}$ groups which belong to amine based modifiers. These bands are slightly shifted to 1539 , 1522 and $1513 \mathrm{~cm}^{-1}$ when the modifications with ammonium, ammonium buffer and DETA (Figure $3 \mathrm{~b})$ are employed. The appearance of the amino group was essential for anticorrosion system. Presence of $\mathrm{C}=\mathrm{O}$ at $1712 \mathrm{~cm}^{-1}$ which belongs to ester group proves successfulness of LFA introduction within the tannin structure. The new peaks (Figure $5 b$ )) at $1396 \mathrm{~cm}^{-1}$ for AT-1,1380 $\mathrm{cm}^{-1}$ for AT-2 and $1478 \mathrm{~cm}^{-1}$ for AT-3 indicate presence of $\mathrm{C}=\mathrm{N}$ group.

The results of the ${ }^{1} \mathrm{H}$ and ${ }^{13} \mathrm{C}$ NMR analysis for all products are as follow (numbering of atoms and ring of interest are given on Figures 3 and 4):

$A T-1:{ }^{1} \mathrm{H}-\mathrm{NMR}$ (DMSO- $\left.\mathrm{d}_{6} ; \delta / \mathrm{ppm}\right): 1.80-3.25$ $(8 \mathrm{H}, \mathrm{s}, \mathrm{N}-\underline{\mathrm{H}}), 3.50\left(3 \mathrm{H}, \mathrm{dd}, \mathrm{C}_{4,8} \mathrm{H}\right), 5.10\left(1 \mathrm{H}, \mathrm{s}, \mathrm{C}_{\text {ring }}{ }^{-}\right.$ $\mathrm{OH}), 6.63\left(1 \mathrm{H}, \mathrm{s}, \mathrm{B}_{\text {ring }} \mathrm{OH}\right), 3.33-3.52(3 \mathrm{H}, \mathrm{dd}$, $\left.3 \mathrm{C}_{4 a, 6} \underline{\mathrm{H}}\right), 4.20-4.70\left(2 \mathrm{H}, \mathrm{m}, 2 \mathrm{C}_{2,3} \mathrm{H}\right), 6.70-7.20(3 \mathrm{H}$, $\left.\mathrm{m}, \mathrm{C}_{2},{ }^{\prime},{ }^{6} \cdot \underline{\mathrm{H}}\right) .{ }^{13} \mathrm{C}-\mathrm{NMR}(\mathrm{\delta} / \mathrm{ppm}): 30\left(\mathrm{C}_{4}\right), 65(\mathrm{C}-\mathrm{N})$, $130\left(\mathrm{C}_{1^{\prime}}\right), 117\left(\mathrm{C}_{2^{\prime}}, \mathrm{C}_{5^{\prime}}, \mathrm{C}_{6^{\prime}}\right), 140\left(\mathrm{C}_{3^{\prime}}\right.$ and $\left.\mathrm{C}_{4^{\prime}}\right), 169$ $\left(\mathrm{C}_{7}\right), 189.5-190\left(\mathrm{C}_{9}\right)[17]$.

The spectra of the product AT-2 [17] were similar to one obtained for AT-1.

AT-3 ${ }^{1} \mathrm{H}-\mathrm{NMR}$ (DMSO- $\left.\mathrm{d}_{6} ; \quad \delta / p p m\right): 1.80-3.25$ $(8 \mathrm{H}, \mathrm{s}, \mathrm{N}-\underline{\mathrm{H}}), 2.89-3.28\left(8 \mathrm{H}, \mathrm{dd}, 4 \mathrm{CH}_{2}\right), 3.50(3 \mathrm{H}$, dd, $\left.\mathrm{C}_{4,8} \mathrm{H}\right), 5.10\left(1 \mathrm{H}, \mathrm{s}, \mathrm{C}_{\text {ring }}-\mathrm{OH}\right), 6.63\left(1 \mathrm{H}, \mathrm{s}, \mathrm{B}_{\text {ring }}-\right.$ $\mathrm{OH})$, 3.33-3.52 (3H, dd, 3C $4 \mathrm{a}, 6 \mathrm{H}), 4.20-4.70(2 \mathrm{H}, \mathrm{m}$,

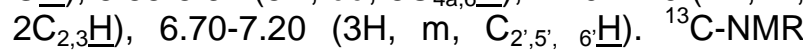
(ठ/ppm): $30\left(\mathrm{C}_{4}\right), 65(\mathrm{C}-\mathrm{N}), 52.60$ and $52.80(4 \mathrm{C}$ from $\mathrm{CH}_{2}$ in DETA), $130\left(\mathrm{C}_{1}\right), 117\left(\mathrm{C}_{2}, \mathrm{C}_{5^{\prime}}, \mathrm{C}_{6^{\prime}}\right)$, $140\left(\mathrm{C}_{3^{\prime}}\right.$ and $\left.\mathrm{C}_{4^{\prime}}\right), 169\left(\mathrm{C}_{7}\right), 189.5-190\left(\mathrm{C}_{9}\right)$ [17].

$E T:{ }^{1} \mathrm{H}-\mathrm{NMR}$ (DMSO- $\left.d_{6} ; \delta / \mathrm{ppm}\right): 2.87(10 \mathrm{H}$, $\left.\mathrm{m}, \quad 5 \mathrm{C}_{11} \underline{\mathrm{H}}_{2}\right), \quad 3.34\left(5 \mathrm{H}, \mathrm{m}, \quad 5 \mathrm{C}_{10} \underline{\mathrm{H}}\right), \quad 3.53-3.73$ $\left(11 \mathrm{H}, \mathrm{m}, 5 \mathrm{C}_{9} \underline{\mathrm{H}}_{2}\right.$ and $\left.\mathrm{C}_{\text {ring }}-\mathrm{C}_{4} \underline{\mathrm{H}}\right), 4.96\left(1 \mathrm{H}, \mathrm{d}, \mathrm{C}_{\text {ring }}{ }^{-}\right.$ $\left.\mathrm{C}_{2} \underline{\mathrm{H}}\right), 5.10\left(1 \mathrm{H}, \mathrm{s}, \mathrm{C}_{\text {ring }}-\mathrm{O} \underline{\mathrm{H}}\right), 5.32-7.31(4 \mathrm{H}, \mathrm{m}$, $\left.\mathrm{C}_{\text {ring }}-\mathrm{C}_{3} \underline{\mathrm{H}}, \quad \mathrm{A}_{\text {ring }}-\mathrm{C}_{6} \underline{\mathrm{H}}, \quad \mathrm{B}_{\text {ring }}-\mathrm{C}_{2}, 6, \underline{\mathrm{H}}_{2}\right) ;{ }^{13} \mathrm{C}-\mathrm{NMR}$ (DMSO- $\left.d_{6} ; \delta / \mathrm{ppm}\right): 40.77\left(\mathrm{C}_{4}\right), 48.2\left(5 \mathrm{C}_{11}\right), 56.57$ $\left(5 \mathrm{C}_{10}\right), 76.67\left(5 \mathrm{C}_{9}\right), 78.04\left(\mathrm{C}_{3}\right), 89.73\left(\mathrm{C}_{2}\right), 93.73$ $\left(\mathrm{C}_{6}\right), 99.01\left(\mathrm{C}_{5}\right), 111.05\left(\mathrm{C}_{2}\right.$ and $\left.\mathrm{C}_{6^{\prime}}\right), 115.52\left(\mathrm{C}_{4 \mathrm{a}}\right)$, $121.93\left(\mathrm{C}_{8}\right), 136.10\left(\mathrm{C}_{1^{\prime}}\right), 142.10\left(\mathrm{C}_{4^{\prime}}\right), 159.55\left(\mathrm{C}_{3^{\prime}}\right.$ and $\left.\mathrm{C}_{5}\right), 161.52\left(\mathrm{C}_{7}\right.$ and $\left.\mathrm{C}_{8 \mathrm{a}}\right)$.

ETA-1: ${ }^{1} \mathrm{H}-\mathrm{NMR}$ (DMSO- $\mathrm{d}_{6}$; $\left.\delta / \mathrm{ppm}\right): 2.24(5 \mathrm{H}$, $\left.\mathrm{s}, \mathrm{C}_{10}-\mathrm{O} \underline{\mathrm{H}}\right), 3.41\left(10 \mathrm{H}, \mathrm{dd}, 5 \mathrm{C}_{11} \underline{\mathrm{H}}_{2}\right), 3.53-3.73(11 \mathrm{H}$, $\mathrm{m}, 5 \mathrm{C}_{9} \underline{\mathrm{H}}_{2}$ and $\left.\mathrm{C}_{\text {ring }}-\mathrm{C}_{4} \underline{\mathrm{H}}\right), 4.21\left(10 \mathrm{H}, \mathrm{s}, 5 \mathrm{C}_{10} \underline{\mathrm{H}}_{2}\right)$, $4.25(5 \mathrm{H}, \mathrm{s}, 5 \mathrm{NH}), 4.96\left(1 \mathrm{H}, \mathrm{d}, \mathrm{C}_{\text {ring }}-\mathrm{C}_{2} \underline{\mathrm{H}}\right), 5.10(1 \mathrm{H}$, $\left.\mathrm{s}, \mathrm{C}_{\text {ring }}-\mathrm{O} \underline{\mathrm{H}}\right), 5.32-7.31\left(4 \mathrm{H}, \mathrm{m}, \mathrm{C}_{\text {ring }}-\mathrm{C}_{3} \underline{\mathrm{H}}, \mathrm{A}_{\text {ring }}-\mathrm{C}_{6} \underline{\mathrm{H}}\right.$, $\left.\mathrm{B}_{\text {ring }}-\mathrm{C}_{2}, 6, \underline{H}_{2}\right), \quad 14.00 \quad(5 \mathrm{H}, \quad \mathrm{s}, \quad 5 \mathrm{~S} \underline{\mathrm{H}}) ;{ }^{13} \mathrm{C}-\mathrm{NMR}$ (DMSO- $\left.\mathrm{d}_{6} ; \delta / \mathrm{ppm}\right): 35.2\left(5 \mathrm{C}_{11}\right), 40.77\left(\mathrm{C}_{4}\right), 63.04$ $\left(5 \mathrm{C}_{10}\right), 76.67\left(5 \mathrm{C}_{9}\right), 78.04\left(\mathrm{C}_{3}\right), 89.73\left(\mathrm{C}_{2}\right), 93.73$ $\left(\mathrm{C}_{6}\right), 99.01\left(\mathrm{C}_{5}\right), 111.05\left(\mathrm{C}_{2}\right.$, and $\left.\mathrm{C}_{6^{\prime}}\right), 115.52\left(\mathrm{C}_{4 \mathrm{a}}\right)$, $121.93\left(\mathrm{C}_{8}\right), 136.10\left(\mathrm{C}_{1^{\prime}}\right), 142.10\left(\mathrm{C}_{4^{\prime}}\right), 159.55\left(\mathrm{C}_{3^{\prime}}\right.$ and $\left.\mathrm{C}_{5}\right), 161.52\left(\mathrm{C}_{7}\right.$ and $\left.\mathrm{C}_{8 \mathrm{a}}\right), 180.62\left(5 \mathrm{C}_{13}\right)$, $195.40\left(5 \mathrm{C}_{14}\right)$.

ETA-2: ${ }^{1} \mathrm{H}-\mathrm{NMR}$ (DMSO- $\left.\mathrm{d}_{6} ; \mathrm{\delta} / \mathrm{ppm}\right): 2.24(5 \mathrm{H}$, $\left.\mathrm{s}, \mathrm{C}_{10}-\mathrm{OH}\right), 3.41\left(10 \mathrm{H}, \mathrm{dd}, 5 \mathrm{C}_{11} \underline{\mathrm{H}}_{2}\right), 3.53-3.73$ $\left(11 \mathrm{H}, \mathrm{m}, 5 \mathrm{C}_{9} \mathrm{H}_{2}\right.$ and $\left.\mathrm{C}_{\text {ring }}-\mathrm{C}_{4} \mathrm{H}\right), 4.21(10 \mathrm{H}, \mathrm{s}$, $\left.5 \mathrm{C}_{10} \underline{\mathrm{H}}_{2}\right), 4.25(5 \mathrm{H}, \mathrm{s}, 5 \mathrm{NH}), 4.96\left(1 \mathrm{H}, \mathrm{d}, \mathrm{C}_{\text {ring }}{ }^{-}\right.$ $\left.\mathrm{C}_{2} \underline{\mathrm{H}}\right), 5.10\left(1 \mathrm{H}, \mathrm{s}, \mathrm{C}_{\text {ring }}-\mathrm{OH}\right), 5.32-7.31(4 \mathrm{H}, \mathrm{m}$, $\left.\mathrm{C}_{\text {ring }}-\mathrm{C}_{3} \underline{\mathrm{H}}, \mathrm{A}_{\text {ring }}-\mathrm{C}_{6} \underline{\mathrm{H}}, \mathrm{B}_{\text {ring }}-\mathrm{C}_{2}, 6, \underline{\mathrm{H}_{2}}\right), 7.60-7.90(4 \mathrm{H}$, dd, $\left.4 \mathrm{C}_{14,15,16,18} \mathrm{H}\right), 8.50-9.20\left(3 \mathrm{H}, \mathrm{m}, \mathrm{C}_{13,17} \mathrm{H}\right) ;{ }^{13} \mathrm{C}-$ NMR (DMSO- $\left.d_{6} ; \delta / p p m\right): 35.2\left(5 \mathrm{C}_{11}\right), 40.77\left(\mathrm{C}_{4}\right)$, $63.04\left(5 \mathrm{C}_{10}\right), 76.67\left(5 \mathrm{C}_{9}\right), 78.04\left(\mathrm{C}_{3}\right), 89.73\left(\mathrm{C}_{2}\right)$, $93.73\left(\mathrm{C}_{6}\right), 99.01\left(\mathrm{C}_{5}\right), 111.05\left(\mathrm{C}_{2}\right.$, and $\left.\mathrm{C}_{6}\right), 115.52$ $\left(\mathrm{C}_{4 \mathrm{a}}\right), 118.9\left(5 \mathrm{C}_{18}\right), 119.12\left(5 \mathrm{C}_{12 \mathrm{a}}\right), 121.93\left(\mathrm{C}_{8}\right)$, $123.94\left(5 \mathrm{C}_{13}\right), 127.82\left(5 \mathrm{C}_{14}\right), 131.28\left(5 \mathrm{C}_{15}\right.$ and $\left.5 \mathrm{C}_{16}\right), 135.12\left(5 \mathrm{C}_{12}\right), 136.10\left(\mathrm{C}_{1^{\prime}}\right), 142.10\left(\mathrm{C}_{4^{\prime}}\right)$, $147.80\left(5 \mathrm{C}_{16 \mathrm{a}}\right), 153.17\left(5 \mathrm{C}_{17}\right), 159.55\left(\mathrm{C}_{3^{\prime}}\right.$ and $\left.\mathrm{C}_{5^{\prime}}\right)$, $161.52\left(\mathrm{C}_{7}\right.$ and $\left.\mathrm{C}_{8 \mathrm{a}}\right)$.

ETA-3: ${ }^{1} \mathrm{H}-\mathrm{NMR}$ (DMSO- $\left.d_{6} ; \quad \delta / p p m\right): 2.24$ $\left(5 \mathrm{H}, \mathrm{s}, \mathrm{C}_{10}-\mathrm{O} \underline{\mathrm{H}}\right), 3.41\left(10 \mathrm{H}, \mathrm{dd}, 5 \mathrm{C}_{11} \underline{\mathrm{H}}_{2}\right), 3.53-$ $3.73\left(11 \mathrm{H}, \mathrm{m}, 5 \mathrm{C}_{9} \mathrm{H}_{2}\right.$ and $\left.\mathrm{C}_{\text {ring }}-\mathrm{C}_{4} \mathrm{H}\right), 4.21(10 \mathrm{H}$, $\left.\mathrm{s}, 5 \mathrm{C}_{10} \underline{\mathrm{H}}_{2}\right), 4.25(5 \mathrm{H}, \mathrm{s}, 5 \mathrm{NH}), 4.96\left(1 \mathrm{H}, \mathrm{d}, \mathrm{C}_{\text {ring }}{ }^{-}\right.$ $\mathrm{C}_{2}$ H $), 5.10\left(1 \mathrm{H}, \mathrm{s}, \mathrm{C}_{\text {ring }}-\mathrm{OH}\right), \quad 5.32-7.31(4 \mathrm{H}, \mathrm{m}$, $\left.\mathrm{C}_{\text {ring }}-\mathrm{C}_{3} \underline{\mathrm{H}}, \mathrm{A}_{\text {ring }}-\mathrm{C}_{6} \underline{\mathrm{H}}, \mathrm{B}_{\text {ring }}-\mathrm{C}_{2}, 6 \underline{\mathrm{H}}_{2}\right), 7.40-7.80(3 \mathrm{H}$,

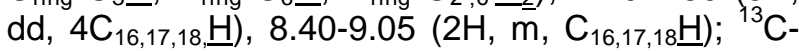
NMR (DMSO- $\left.d_{6} ; \delta / p p m\right): 35.2\left(5 \mathrm{C}_{11}\right), 40.77\left(\mathrm{C}_{4}\right)$, $63.04\left(5 \mathrm{C}_{10}\right), 76.67\left(5 \mathrm{C}_{9}\right), 78.04\left(\mathrm{C}_{3}\right), 89.73\left(\mathrm{C}_{2}\right)$, $93.73\left(\mathrm{C}_{6}\right), 99.01\left(\mathrm{C}_{5}\right), 111.05\left(\mathrm{C}_{2^{\prime}}\right.$ and $\left.\mathrm{C}_{6^{\prime}}\right), 115.52$ $\left(\mathrm{C}_{4 \mathrm{a}}\right), 118.9\left(5 \mathrm{C}_{18}\right), 119.12\left(5 \mathrm{C}_{12 \mathrm{a}}\right), 121.93\left(\mathrm{C}_{8}\right)$, $123.63\left(5 \mathrm{C}_{14}\right), 125.84\left(5 \mathrm{C}_{13}\right), 127.28\left(5 \mathrm{C}_{16}\right.$ and $\left.5 \mathrm{C}_{17}\right), 131.80\left(5 \mathrm{C}_{16 \mathrm{a}}\right), 135.12\left(5 \mathrm{C}_{12}\right), 136.10\left(\mathrm{C}_{1^{\prime}}\right)$, $142.10\left(\mathrm{C}_{4^{\prime}}\right), 152.36\left(5 \mathrm{C}_{15}\right), 159.55\left(\mathrm{C}_{3^{\prime}}\right.$ and $\left.\mathrm{C}_{5^{\prime}}\right)$, $161.52\left(\mathrm{C}_{7}\right.$ and $\left.\mathrm{C}_{8 \mathrm{a}}\right)$.

ET-LFA: ${ }^{1} \mathrm{H}-\mathrm{NMR}$ (DMSO- $d_{6}$; $\delta / \mathrm{ppm}$ ): 0.90$1.30\left(85 \mathrm{H}, \mathrm{m}, 5 \mathrm{C}_{20,23-29} \mathrm{H}_{17}\right), 1.35-160(30 \mathrm{H}, \mathrm{dd}$, $\left.5 \mathrm{C}_{17-18} \underline{\mathrm{H}}_{2}, \quad 5 \mathrm{C}_{19,16} \underline{\mathrm{H}}_{21} \quad 5 \mathrm{C}_{14-15} \underline{\mathrm{H}}_{2}\right), \quad 2.32(5 \mathrm{H}, \quad \mathrm{d}$, $\left.5 \mathrm{C}_{13} \underline{\mathrm{H}}\right), 3.65\left(1 \mathrm{H}, \mathrm{d}, \mathrm{C}_{\text {ring }}-\mathrm{C}_{4} \underline{\mathrm{H}}\right), 4.20-4.54(25 \mathrm{H}$, dd, $\left.5 \mathrm{C}_{9-11} \underline{H}_{5}\right), 4.96\left(1 \mathrm{H}, \mathrm{d}, \mathrm{C}_{\text {ring }}-\mathrm{C}_{2} \underline{\mathrm{H}}\right), 5.10(1 \mathrm{H}, \mathrm{s}$, $\left.\mathrm{C}_{\text {ring }} \mathrm{O} \underline{\mathrm{H}}\right), 5.32-7.31\left(4 \mathrm{H}, \mathrm{m}, \mathrm{C}_{\text {ring }}-\mathrm{C}_{3} \underline{\mathrm{H}}, \mathrm{A}_{\text {ring }}-\mathrm{C}_{6} \underline{\mathrm{H}}\right.$, $\left.\mathrm{B}_{\text {ring }}-\mathrm{C}_{2^{\prime}, 6} \underline{\mathrm{H}}_{2}\right) ; 5.43(15 \mathrm{H}, \mathrm{s}, 5 \mathrm{C} \underline{\mathrm{H}}=\mathrm{C} \underline{\mathrm{H}}$ and $5 \mathrm{O} \underline{\mathrm{H}})$; 
${ }^{13} \mathrm{C}-\mathrm{NMR}$ (DMSO-d; $;$ /ppm): $20.1\left(5 \mathrm{C}_{29}\right), 24.0$ $\left(5 \mathrm{C}_{28}\right), 25.9\left(5 \mathrm{C}_{14}\right), 30.09\left(5 \mathrm{C}_{15-19}\right.$ and $\left.5 \mathrm{C}_{24-27}\right)$, $34.2\left(5 \mathrm{C}_{9}, 5 \mathrm{C}_{13}, 5 \mathrm{C}_{20}\right.$ and $\left.5 \mathrm{C}_{23}\right), 68.1\left(5 \mathrm{C}_{10}\right), 72.3$ $\left(5 \mathrm{C}_{11}\right), 78.04\left(\mathrm{C}_{3}\right), 89.73\left(\mathrm{C}_{2}\right), 93.73\left(\mathrm{C}_{6}\right), 99.01$ $\left(\mathrm{C}_{5}\right), 111.05\left(\mathrm{C}_{2}\right.$, and $\left.\mathrm{C}_{6}\right), 115.52\left(\mathrm{C}_{4 \mathrm{a}}\right), 121.93$ $\left(\mathrm{C}_{8}\right), 136.10\left(\mathrm{C}_{1^{\prime}}\right), 142.10\left(\mathrm{C}_{4^{\prime}}\right), 159.55\left(\mathrm{C}_{3^{\prime}}\right.$ and $\left.\mathrm{C}_{5^{\prime}}\right), 161.52\left(\mathrm{C}_{7}\right.$ and $\left.\mathrm{C}_{8 \mathrm{a}}\right)$.

In general complex NMR spectra were obtained, and presented results relate to analysis of obtained spectra which emphasize structure modification in the course of applied syntheses methods. Comparison of NMR spectra of synthesized inhibitors, isolated tannin and commercial tannin help in confirmation of material structure and peak assignments.

\subsection{Determination of epoxy content}

Epoxy content is expressed through the epoxy groups present in ET and amounted to $8.2 \%$. The presence of the epoxy groups within the amino modified materials is difficult to define due to reactions between epoxy and amino/carboxyl linseed oil used for tannin modification, respectively.

\subsection{Rusting test of anticorrosive properties of formulated products}

In order to better understand the influence of alkyd anti-corrosion coatings with additives based groups from amines and fatty acids isolated from

on modified tannins, synthesized inhibitors were used in a three layer protective system (Table 6) and one controllable three in one ( 3 in 1) system with incorporated anticorrosive agents. They are also tested using a standard or modified method/equipment to determine corrosion degree in the wet and salt chamber.

Table 6. Definition of three-layers and limits of thickness of dry film (TDF) of obtained coatings

Tabela 6. Opis troslojnog premaza $i$ debljina suvod filma (TDF) dobijenih premaza

\begin{tabular}{|c|c|c|}
\hline & Type of coating & $\mathrm{TDF}^{\star}, \mu \mathrm{m}$ \\
\hline 1. layer & Anticorrosive & $40-70$ \\
\hline 2. layer* & Intermediary & $40-50$ \\
\hline 3. layer** & Top coat (Gloss coat) & $20-30$ \\
\hline
\end{tabular}

* Thickness of dry film was measured according to ISO 2360; Intermediary coat was produced according to composition Co-1 presented in Table 1 by excluding zinc phosphate; Top coat was based on Co-1 by excluding all filler and pigment from composition.

Physico-chemical and mechanical properties, adhesion and elasticity of alkyd resin anticorrosive coatings before anticorrosive testing were examined, and obtained results are given in Table 7.

Table 7. Physico-chemical properties of the prepared plate with anticorrosive coatings

Tabela 7. Fizičko hemijske osobine pripremljenih ploča sa antikorozionim premazima

\begin{tabular}{|c|c|c|c|c|c|c|c|c|c|}
\hline Coating /properties & $\begin{array}{c}\text { Co- } \\
1\end{array}$ & Co-AT1 & Co-AT2 & Co-AT3 & $\begin{array}{c}\text { Co- } \\
\text { ET }\end{array}$ & $\begin{array}{c}\text { Co- } \\
\text { ETA1 }\end{array}$ & $\begin{array}{c}\text { Co- } \\
\text { ETA2 }\end{array}$ & $\begin{array}{c}\text { Co- } \\
\text { ETA3 }\end{array}$ & $\begin{array}{c}\text { Co- } \\
\text { ETLFA }\end{array}$ \\
\hline Thickness, $\mu \mathrm{m}$ & 129 & 127 & 120 & 128 & 129 & 125 & 120 & 128 & 128 \\
\hline Viscosity, Ford 4 & 173 & 175 & 185 & 188 & 175 & 180 & 184 & 180 & 171 \\
\hline Density, g/cm & 3.60 & 1.52 & 1.56 & 1.55 & 1.52 & 1.53 & 1.55 & 1.54 & 1.50 \\
\hline Hardness, s & 66 & 72 & 77 & 81 & 69 & 82 & 68 & 67 & 85 \\
\hline Gloss, \% & 84 & 74 & 75 & 72 & 79 & 76 & 75 & 78 & 82 \\
\hline $\begin{array}{c}\text { Abrasion, } \\
\text { 0-good, 5-bad }\end{array}$ & 0 & 0 & 0 & 0 & 0 & 0 & 0 & 0 & 0 \\
\hline $\begin{array}{c}\text { Adhesion } \\
\text { 0-good, 5-bad }\end{array}$ & 0 & 0 & 0 & 0 & 0 & 0 & 0 & 0 & 0 \\
\hline $\begin{array}{c}\text { VOC, g/L } \\
\text { Bending, }\end{array}$ & 255 & 255 & 251 & 255 & 253 & 255 & 251 & 253 & 253 \\
\hline 0-good, 5-bad & 0 & 0 & 0 & 0 & 0 & 0 & 0 & 0 & 0 \\
\hline $\begin{array}{c}\text { Coverage, } \\
\text { o-good, 5-bad }\end{array}$ & 0 & 0 & 0 & 0 & 0 & 0 & 0 & 0 & 0 \\
\hline Impact Resistance & $>30$ & $>30$ & $>30$ & $>30$ & $>30$ & $>30$ & $>30$ & $>30$ & $>30$ \\
\hline Elasticity, mm & 7.4 & 7.6 & 7.5 & 7.7 & 7.6 & 7.8 & 7.6 & 7.7 & 7.9 \\
\hline
\end{tabular}

The thicknesses of the anticorrosive films are from 120 to $129 \mu \mathrm{m}$. On the basis of the obtained results it can be concluded that anticorrosive coatings meet the requirements defined by the standards. In order to select anticorrosive agents protective coatings (Table 7 ) with respect to rusting and adhesion (120 $\mathrm{h}$ exposure) to select the most potential ones. Obtained results are given in Table 8. the preliminary tests were performed for all 
Table 8. Anticorrosive properties of all anticorrosive coating applied in a three layer system (Test duration: 120 hours)

Tabela 8. Antikoroziona svojstva svih antikorozionih premaza u troslojnom sistemu (Trajanje ispitivanja 120 sati)

\begin{tabular}{|c|c|c|c|c|c|c|c|c|c|}
\hline Coating/properties & $\begin{array}{c}\text { Co- } \\
1\end{array}$ & $\begin{array}{c}\text { Co- } \\
\text { AT1 }\end{array}$ & $\begin{array}{c}\text { Co- } \\
\text { AT2 }\end{array}$ & $\begin{array}{c}\text { Co- } \\
\text { AT3 }\end{array}$ & $\begin{array}{c}\text { Co- } \\
\text { ET }\end{array}$ & $\begin{array}{c}\text { Co- } \\
\text { ETA1 }\end{array}$ & $\begin{array}{c}\text { Co- } \\
\text { ETA2 }\end{array}$ & $\begin{array}{c}\text { Co- } \\
\text { ETA3 }\end{array}$ & $\begin{array}{c}\text { Co- } \\
\text { ETLFA }\end{array}$ \\
\hline SRPS EN ISO 4628-3 (rusting) & Ri2 & Ri2 & Ri2 & Ri1 & Ri2 & Ri1 & Ri1 & Ri2 & Ri1 \\
\hline SRPS EN ISO 2409 (adhesion) & 2 & 1 & 2 & 1 & 2 & 1 & 2 & 1 & 1 \\
\hline
\end{tabular}

Preliminary results of anticorrosive tests showed the best properties of Co-AT3, Co-ETA1 and Co-ETLFA coating.

As the coatings Co-ETA1 and Co-ETLFA showed better properties, in further studies synthesized anti-corrosive agent ET-A1 and ETLFA was used as a three-layer system as it is given in Table 6. The anticorrosive properties of the three-layer coating either without (Co-1 as reference) and with modified tannin anticorrosive agents (Co-ETA1 and Co-ETLFA) formed by three layers coatings was comparatively studied with one pot system (3 in 1). Three in one system should justify the idea of simplified application procedure and anticorrosive properties of obtained coating with respect to more operationally complex three layer coating. The characteristics of the prepared protective systems after the exposure to wet chamber are tabulated in Tables 9 and 10.

Table 9. Anticorrosive properties of Co-ETA1 (three layer coating)

Tabela 9. Antikoroziona svojstva Co-ETA1 (troslojni premaz)

\begin{tabular}{|c|c|c|c|}
\hline $\begin{array}{l}\text { Evaluation after testing } \\
\text { according to SRPS ISO 6270-1 }\end{array}$ & $\begin{array}{c}\text { Plate } \\
1\end{array}$ & $\begin{array}{l}\text { Plate } \\
2\end{array}$ & $\begin{array}{l}\text { Plate } \\
3\end{array}$ \\
\hline $\begin{array}{l}\text { SRPS EN ISO 4628-2 } \\
\text { (blistering) }\end{array}$ & 0 & 0 & 0 \\
\hline $\begin{array}{l}\text { SRPS EN ISO 4628-3 } \\
\text { (rusting) }\end{array}$ & Rio & RiO & Rio \\
\hline $\begin{array}{l}\text { SRPS EN ISO 4628-4 } \\
\text { (cracking) }\end{array}$ & 0 & 0 & 0 \\
\hline $\begin{array}{l}\text { SRPS EN ISO 4628-5 } \\
\text { (delamination) }\end{array}$ & 0 & 0 & 0 \\
\hline Thickness of dry film, $\mu \mathrm{m}$ & 120 & 125 & 124 \\
\hline $\begin{array}{l}\text { SRPS EN ISO } 2409 \\
\text { (adhesion) }\end{array}$ & 0 & 0 & 0 \\
\hline
\end{tabular}

During $48 \mathrm{~h}$ exposure in a wet chamber, plates covered with protective coatings Co-ETA2 and CoETLFA did not show noticeable rusting and color change, whereas plates with standard additive, Co1 , suffered a mild film deterioration and hardly noticeable surface roughening. While examining plates with Co-ETA2 and Co-ETLFA there were no film defects observed as blistering, rusting, cracking or flaking according to SRPS EN ISO 6270-1 standards.

Table 10. Anticorrosive properties of Co-ETLFA (three layer coating)

Tabela 10. Antikoroziona svojstva Co-ETLFA (troslojni premaz)

\begin{tabular}{|l|c|c|c|}
\hline $\begin{array}{l}\text { Evaluation after testing } \\
\text { according to SRPS ISO } \\
6270-1\end{array}$ & $\begin{array}{c}\text { Plate } \\
1\end{array}$ & $\begin{array}{c}\text { Plate } \\
2\end{array}$ & $\begin{array}{c}\text { Plate } \\
3\end{array}$ \\
\hline $\begin{array}{l}\text { SRPS EN ISO 4628-2 } \\
\text { (blistering) }\end{array}$ & 0 & 0 & 0 \\
\hline $\begin{array}{l}\text { SRPS EN ISO 4628-3 } \\
\text { (rusting) }\end{array}$ & Ri0 & Ri0 & Ri0 \\
\hline $\begin{array}{l}\text { SRPS EN ISO 4628-4 } \\
\text { (cracking) }\end{array}$ & 0 & 0 & 0 \\
\hline $\begin{array}{l}\text { SRPS EN ISO 4628-5 } \\
\text { (delamination) }\end{array}$ & 0 & 0 & 0 \\
\hline \begin{tabular}{l} 
Thickness of dry film, $\mu \mathrm{m}$ \\
\hline $\begin{array}{l}\text { SRPS EN ISO 2409 } \\
\text { (adhesion) }\end{array}$
\end{tabular} & 128 & 120 & 125 \\
\hline
\end{tabular}

The characteristics of the prepared protective systems Co-ETA1 and Co-ETLFA (three layer coatings) after appropriate time of exposure to a salt chamber are tabulated in Tables 11 and 12 (48 h), and Tables 13 and 14 (120 h).

Table 11. Anticorrosive properties of Co-ETA1 (test duration: 48 hours)

Tabela 11. Antikoroziona svojstva Co-ETA1 (trajanje testa 48 sati)

\begin{tabular}{|l|c|c|c|}
\hline $\begin{array}{l}\text { Evaluation after testing } \\
\text { according to SRPS ISO 9227 }\end{array}$ & $\begin{array}{c}\text { Plate } \\
1\end{array}$ & $\begin{array}{c}\text { Plate } \\
2\end{array}$ & $\begin{array}{c}\text { Plate } \\
3\end{array}$ \\
\hline $\begin{array}{l}\text { SRPS EN ISO 4628-2 } \\
\text { (blistering) }\end{array}$ & 1 & 0 & 1 \\
\hline $\begin{array}{l}\text { SRPS EN ISO 4628-3 } \\
\text { (rusting) }\end{array}$ & Ri1 & Ri0 & Ri0 \\
\hline $\begin{array}{l}\text { SRPS EN ISO 4628-4 } \\
\text { (cracking) }\end{array}$ & 0 & 1 & 0 \\
\hline $\begin{array}{l}\text { SRPS EN ISO 4628-5 } \\
\text { (delamination) }\end{array}$ & 0 & 0 & 0 \\
\hline Thickness of dry film, $\mu \mathrm{m}$ & 130 & 132 & 129 \\
\hline $\begin{array}{l}\text { SRPS EN ISO 2409 } \\
\text { (adhesion) }\end{array}$ & 0 & 1 & 0 \\
\hline
\end{tabular}


Table 12. Anticorrosive properties of Co-ETLFA (test duration: 48 hours)

Tabela 12. Antikoroziona svojstva Co-ETLFA (trajanje testa 48 sati)

\begin{tabular}{|l|c|c|c|}
\hline $\begin{array}{l}\text { Evaluation after testing } \\
\text { according to SRPS ISO 9227 }\end{array}$ & $\begin{array}{c}\text { Plate } \\
1\end{array}$ & $\begin{array}{c}\text { Plate } \\
2\end{array}$ & $\begin{array}{c}\text { Plate } \\
3\end{array}$ \\
\hline $\begin{array}{l}\text { SRPS EN ISO 4628-2 } \\
\text { (blistering) }\end{array}$ & 0 & 0 & 0 \\
\hline $\begin{array}{l}\text { SRPS EN ISO 4628-3 } \\
\text { (rusting) }\end{array}$ & Ri0 & Ri1 & Ri0 \\
\hline $\begin{array}{l}\text { SRPS EN ISO 4628-4 } \\
\text { (cracking) }\end{array}$ & 0 & 1 & 0 \\
\hline $\begin{array}{l}\text { SRPS EN ISO 4628-5 } \\
\text { (delamination) }\end{array}$ & 1 & 0 & 0 \\
\hline Thickness of dry film, $\mu \mathrm{m}$ & 125 & 128 & 131 \\
\hline $\begin{array}{l}\text { SRPS EN ISO 2409 } \\
\text { (adhesion) }\end{array}$ & 0 & 1 & 0 \\
\hline
\end{tabular}

Table 13. Anticorrosive properties of Co-ETA1 (test duration: 120 hours)

Tabela 13. Antikoroziona svojstva Co-ETA1 (trajanje testa 120 sati)

\begin{tabular}{|l|c|c|c|}
\hline $\begin{array}{l}\text { Evaluation after testing } \\
\text { according to SRPS ISO 9227 }\end{array}$ & $\begin{array}{c}\text { Plate } \\
1\end{array}$ & $\begin{array}{c}\text { Plate } \\
2\end{array}$ & $\begin{array}{c}\text { Plate } \\
3\end{array}$ \\
\hline $\begin{array}{l}\text { SRPS EN ISO 4628-2 } \\
\text { (blistering) }\end{array}$ & 1 & 1 & 1 \\
\hline $\begin{array}{l}\text { SRPS EN ISO 4628-3 } \\
\text { (rusting) }\end{array}$ & Ri1 & Ri1 & Ri1 \\
\hline $\begin{array}{l}\text { SRPS EN ISO 4628-4 } \\
\text { (cracking) }\end{array}$ & 0 & 1 & 1 \\
\hline $\begin{array}{l}\text { SRPS EN ISO 4628-5 } \\
\text { (delamiantion) }\end{array}$ & 1 & 0 & 0 \\
\hline Thickness of dry film, $\mu \mathrm{m}$ & 135 & 137 & 133 \\
\hline $\begin{array}{l}\text { SRPS EN ISO 2409 } \\
\text { (adhesion) }\end{array}$ & 1 & 1 & 1 \\
\hline
\end{tabular}

Table 14. Anticorrosive properties of Co-ETLFA (test duration: 120 hours)

Tabela 14. Antikoroziona svojstva Co-ETLFA (trajanje testa 120 sati)

\begin{tabular}{|l|c|c|c|}
\hline $\begin{array}{l}\text { Evaluation after testing } \\
\text { according to SRPS ISO 9227 }\end{array}$ & $\begin{array}{c}\text { Plate } \\
1\end{array}$ & $\begin{array}{c}\text { Plate } \\
2\end{array}$ & $\begin{array}{c}\text { Plate } \\
3\end{array}$ \\
\hline $\begin{array}{l}\text { SRPS EN ISO 4628-2 } \\
\text { (blistering) }\end{array}$ & 0 & 1 & 1 \\
\hline $\begin{array}{l}\text { SRPS EN ISO 4628-3 } \\
\text { (rusting) }\end{array}$ & Ri0 & Ri1 & Ri1 \\
\hline $\begin{array}{l}\text { SRPS EN ISO 4628-4 } \\
\text { (cracking) }\end{array}$ & 0 & 1 & 1 \\
\hline $\begin{array}{l}\text { SRPS EN ISO 4628-5 } \\
\text { (delamination) }\end{array}$ & 1 & 0 & 0 \\
\hline Thickness of dry film, $\mu \mathrm{m}$ & 130 & 133 & 132 \\
\hline $\begin{array}{l}\text { SRPS EN ISO 2409 } \\
\text { (adhesion) }\end{array}$ & 0 & 0 & 1 \\
\hline
\end{tabular}

After the exposure of $120 \mathrm{~h}$ the obtained results (Tables 13 and 14), compared to the results for standard plate Co-1 and alkyd paint 3 in 1 (data not presented) showed that the both three layer and 3 in 1 system satisfies standard requirements while the basic alkyd paint $\mathrm{Co}^{-1}$ is not adequate to be used as anticorrosive paints. Test sample Co-1 shows noticeable film destruction with intensive rusting, and these results indicate significance of added anticorrosive agents.

The tests for thickness of blistering, adhesion and cracking show better results for anticorrosive three layered system Co-ETA1 and Co-ETLFA showed good anticorrosive properties, while three in one, shows appropriate adhesion failure and blistering. Therefore, it can be concluded that the anticorrosive system 3 in 1 does not meet the requirements of the standards, and that the three layer coating system and the final rapid-drying paint meet the requirements prescribed by the standards.

Corrosion inhibition of those synthesized tannin based additives may be explained by chemical structure of the prepared compounds. Namely, tannin itself is a biopolymer with an aromatic structure and his $\mathrm{pK}_{\mathrm{a}}$ value does not exceed more than 7 as a result of plenty hydroxy groups bounded on benzene rings. That is a very low value and tannin itself could not be used as a corrosion inhibitor. Conversely, amines with low molecular weight lack in dispersity, especially amines which have good solubility in water. Alkyd based amino modified tannin anticorrosive coating have both benefits. Tannin matrix disperses the amine functional group and at the same time creates a passivating layer which impacts diffusion of oxygen resulting in inhibition of the cathode halfreaction (oxygen reduction). Free electron couples on nitrogen atoms from amine functional group also affect the oxidation of the metal for they participate in creation of the metal complex which precipitates on the metal surface slowing the rate of the metal oxidation. Nevertheless, anticorrosive additives ETA(1-3) and ETA-LFA showed good compatibility and easy procesability in the course of grinding process. Synthesized materials act as processing aids, and ET-LFA have high gloss comparable to Co- 1 coating. Considering Co-ETLFA, anticorrosive potential of LFA modifying structure contribute to better adhesion, structural integrity and improvement of film hydrophobicity. In this case presence of LFA modifying agent contribute to better dispersibility in alkyd media, participate in cross-linking reactivity causing increased film homogeneity and network density which behave as a good protective barrier for oxygen, water and ion transport.

Study on anticorrosive properties of nine anticorrosive agents in alkyd based coatings showed 
diversity of physico-chemical and anticorrosion potential. In this sense, the choice of anti-corrosive agent and metal protection system could not be analyzed and selected according to presented results but techno-economic analysis would also be the decisive criteria in determining the efficiency of production/implementation of a particular protection system. A preliminary techno-economic analysis shows that the use of anticorrosive agents ET-LFA and ETA-1 is more functional, and in further testing and production at the industrial level, the aforementioned anti-corrosion additive will be used and studied in detail.

\section{CONCLUSION}

The effect of natural tannin polymers modified with $\left(\mathrm{NH}_{3(\mathrm{aq})}\right)$, $\left(\mathrm{NH}_{3(\mathrm{aq})}\right) / \mathrm{NH}_{4} \mathrm{Cl}$ buffer, DETA in one step modification, and heterocyclic amines and fatty acids of linseed oil in a two steps process on corrosion resistance of alkyd based coatings was studied. Synthesized inhibitors have shown high resistance and significant inhibiting effect, and the best properties were obtained using ET-LFA and ETA-1 inhibitors. Coatings with the addition of new inhibitors showed better adhesion, abrasion, gloss, and viscosity, and have proven to have good anticorrosion properties. Additionally, processability of alkyd coating with added synthesized anticorrosive agents was similar/better to/than coating with zincphosphate addition, while Co-ETLFA was easily milled even for shorter time.

Synthesized inhibitors were applied in two different protective systems: three layer system and comparative three in one system, whereas the former one was found to possess better anticorrosive performance.

Anticorrosive tannin modified compounds represent synergetic inhibitors due to effect of both tannin basic structure and modifying reagent. These compounds represent noble biopolymer corrosion inhibitors and further researches should be pointed towards optimizing the synthesis itself, detail study on anticorrosive mechanism and finding the defects of those coatings so they could be eliminated or mitigated.

\section{Acknowledgements}

The authors acknowledge the financial support from the Ministry of Education, Science and Technological Developments of the Republic of Serbia, Project Nos. III45019, TR34028, Ol172057 and Ol176018.

\section{REFERENCES}

[1] A.Gandini (2008) Polymers from renewable resources: A Challenge for the future of macromolecular materials, Macromolecules, 41(24), 9491-9504.
[2] D.E.García, W.G.Glasser, A.Pizzi, S.P. Paczkowski, M.P.Laborie (2016) Modification of condensed tannins: From polyphenol chemistry to materials engineering, New Journal of Chemistry, 40(1), 3649.

[3] A.E.Hagerman (2002) Tannin Chemistry, The Tannin Handbook, Miami University, Oxford $\mathrm{OH}$ 45056, Ohio, p. 1-5.

[4] V.Koleckar et al. (2008) Condensed and hydrolysable tannins as antioxidants influencing the health, Mini-Reviews in Medicinal Chemistry, 8(5), 436-447.

[5] A.Gambuti, L.Picariello, A.Rinaldi, L.Moio (2018) Evolution of Sangiovese wines with varied tannin and anthocyanin ratios during oxidative aging, Frontiers Chemistry, 6(63), 1-11.

[6] Y.Shirmohammadli, D.Efhamisisi, A.Pizzi (2018) Tannins as a sustainable raw material for green chemistry: A review, Industrial Crops and Products, 126, 316-332.

[7] W.J.Grigsby (2018) Photooxidative stability provided by condensed tannin additives in acrylicbased surface coatings on exterior exposure, Journal of Coatings Technology and Research, 15(6), 1273-1282.

[8] L.Chupin, B.Charrier, A.Pizzi, A.Perdomo, F. Charrier-El Bouhtoury (2015) Study of thermal durability properties of tannin-lignosulfonate adhesives, J. of Thermal Analysis and Calorimetry, 119(3), 1577-1585.

[9] C.G.Silva. C.R.E.Frollini (2013) Phenolic resins as a matrix material inadvanced fiber-reinforced polymer (FRP) composites, Advanced Fibre-Reinforced Polymer (FRP) Composites for Structural Applications, Woodhead Publishing, Sawston, Cambridge, p. 7-43.

[10] G.Matamala, W.Smeltzer, G.Droguett (2000) Comparison of steel anticorrosive protection formulated with natural tannins extracted from acacia and from pine bark, Corrosion Science, 42(8), 1351-1362.

[11] R.S.Peres, E.Cassel, C.A.Ferreira, D.S.Azambuja (2014) Black wattle tannin as a zinc phosphating coating sealer, Surface and Interface Analysis, 46(1), 1-6.

[12] M.Goyal, S.Kumar, I.Bahadur, C.Verma, E.E. Ebenso (2018) Organic corrosion inhibitors for industrial cleaning of ferrous and non-ferrous metals in acidic solutions: A review, Journal of Molecular Liquids, 256, 565-573.

[13] P.Selvakumar, B.B.Karthik, C.Thangavelu (2013) Corrosion inhibition study of stainless steel in acidic medium-an overview, Research Journal of Chemical Sciences, 16(4) 87-95.

[14] H.E.Townsend (1994) ASM Handbook: Vol 05 Surface Engineering, American Society for Metals,Ohio.

[15] A.V.Zmozinski, R.S.Peres, K.Freiberger, C.A. Ferreira, S.M.M.Tamborim, D.S.Azambuja (2018) Zinc tannate and magnesium tannate as anticorrosion pigments in epoxy paint formulations, Progress in Organic Coatings, 121, 23-29. 
[16] I.Popovic, J.Rusmirovic, M.Rancic, A.Tasic, D. Lazic, A.Marinkovic (2015) Synthesis of highperformance alkyd anticorrosion coatings based on waste poly(ethyleneterephthalate), Zastita Materijala, 56(4), 483-491.

[17] F.Braghiroli et al. (2013) Reaction of condensed tannins with ammonia, Industrial Crops and Products, 44, 330-335.

[18] T.C.Patton (1962) Alkyd resin technology, Interscience Publishing, New York.

[19] P.M.Spasojević et al (2015) High performance alkyd resins synthesized from postconsumer PET bottles, Royal Society of Chemistry, 5(76), 62273-62283.

[20] ASTMD1639 (2014) Test Method for Acid Value of Organic Coating Materials.

[21] G.A.Stenmark(1957) Argentimetric method for epoxides, Analytical Chemistry, 29(9), 1367-1369.

[22] ASTMD 2074 - 98 (1998) Standard Test Methods for Total, Primary, Secondary, and Tertiary Amine Values of Fatty Amines by Alternative Indicator Method.

[23] ASTM D1957-86R01 (2014) Test Method for Hydroxyl Value of Fatty Oils and Acids.

[24] SRPS EN ISO 4628 (1998) Paints and varnishes Evaluation of degradation of coatings - Designation of quantity and size of defects. and of intensity of uniform changes in appearance.

[25] ASTM D1200-10 (2005) Standart Test Method for Viscosity by Ford Viscosity Cup.
[26] ASTM D 4366 (2014) Standard Test Methods for Hardness of Organic Coatings by Pendulum Damping Tests.

[27] SRPS EN ISO 2360 (2017) Non-conductive coatings on non-magnetic electrically conductive base metals - Measurement of coating thickness Amplitude-sensitive eddy-current method.

[28] SRPS EN ISO 2409 (2016) Paints and varnishes Cross-cut test

[29] ASTM D 4060-10 (2010) Standard Test Method for Abrasion Resistance of Organic Coatings by the Taber.

[30] SRPS EN ISO 11890 (2010) Paints and varnishes Determination of volatile organic compound (VOC) content

[31] ASTM D523-08 (2008) Standard Test Method for Specular Gloss1 This.

[32] ASTM D2794-93 (2010) Standard Test Method for Resistance of Organic Coatings to the Effects of Rapid Deformation (Impact)1.

[33] A. Arbenz, L. Avérous (2015) Chemical modification of tannins to elaborate aromatic biobased macromolecular architectures, Green Chemistry, 17(5), 2626-2646.

[34] K.Hashida, R.Makino, S.Ohara (2009) Amination of pyrogallol nucleus of condensed tannins and related polyphenols by ammonia water treatment, Holzforschung, 63(3), 319-326.

[35] G.Tondi, A.Petutschnigg (2015) Middle infrared (ATR FT-MIR) characterization of industrial tannin extracts,Industrial Crops and Products,65, 422-428.

\title{
IZVOD
}

\section{PRIMENA MODIFIKOVANIH TANINA U ANTIKOROZIONIM ALKIDNIM PREMAZIMA}

$U$ ovom radu prikazana je sinteza antikorozionih aditiva na bazi hemijski modifikovanog tanina $i$ njihova primena $u$ alkidnim premazima $u$ cilju poboljšanja antikorozionih svojstava. Prikazane su dve metode modifikacije tanina: direktna modifikacija tanina primenom amonijum-hidroksida, amonijum-hidroksid/amonijum-hlorid pufera ili dietilentriamina (DETA); i dvostepena modifikacija tanina koja u prvom stupnju uključuje modifikaciju epihlorhidrinom sa ciljem da se dobije tannin sa epoksi terminiranim funkcionalnim grupama, ET, i modifikaciju ET tanina sa heteroaromatičnim aminima ili masnim kiselinama izolovanim iz lanenog ulja (LFA) u drugom stupnju. Sintetisani antikorozioni aditivi su okarakterisani primenom ATR-FTIR, ${ }^{1} \mathrm{H} i{ }^{13} \mathrm{C} N M R$ spektroskopija, $i$ elementalnom analizom. Sadržaj epoksi, amino, hidroksilnih $i$ karboksilnih grupa i vrednost jodnog broja sintetisanih aditiva određen je prema standardnim metodama. Alkidni premazi koji sadrže antikorozione aditive na bazi modifikovanog tanina ispitani su prema standardnoj SRPS EN ISO 4628 metodi. Antikorozivni alkidni premazi na bazi modfikovanih tanina pokazali su poboljšane antikorozione karakteristike $i$ adheziju u poređenju sa alkidnim premazom na bazi cink-fosfata. Alkidni premazi koji sadrže dvostepeno modifikovani tanin sa LFA i 2-amino-5-merkapto-1,3,4tiadiazolom pokazali su najbolje antikorozione karakteristike.

Ključne reči: modifikovani tanini, antikorozioni aditivi, korozija, alkidni premazi

\author{
Naučni rad \\ Rad primljen: 12. 12. 2018. \\ Rad prihvaćen: 10. 01. 2019. \\ Rad je dostupan na sajtu: www.idk.org.rs/casopis
}

(c) 2019 Authors. Published by Engineering Society for Corrosion. This article is an open access article distributed under the terms and conditions of the Creative Commons Attribution 4.0 International license (https://creativecommons.org/licenses/by/4.0/) 